\title{
Palynomorphs of the Normapolles group and related plant mesofossils from the Iharkút vertebrate site, Bakony Mountains (Hungary)
}

\author{
Emese Réka Bodor, \\ Department of Paleontology, Eötvös Loránd University, \\ Budapest
}

\section{Viktória Baranyi}

Department of Paleontology, Eötvös Loránd

University, Budapest

Department of Geological and Geophysical Collections, Geological and Geophysical Institute of Hungary, Budapest

\begin{abstract}
Palynological and paleobotanical investigation of bonebeds and other strata of the Csehbánya Formation from the vertebrate locality at Iharkút (Bakony Mts, Hungary) reveals well-preserved Santonian palynological assemblages dominated by the Normapolles group, with a minor component consisting of other angiosperm pollen, some gymnosperm pollen, and spores. Eleven species of Normapolles-type pollen grains belonging to seven genera and fruit remains of a new taxon, Sphaeracostata barbackae gen. et sp. nov., are described. The new species is very abundant in the material, represented by ca. 1000 specimens. The genus Caryanthus Friis and an unnamed form previously reported from Haţeg by Lindfors et al. (2010) are also present.

Plants producing Normapolles-type pollen grains diversified during the Late Cretaceous, with a bloom in the Santonian. The palynostratigraphy of the Upper Cretaceous terrestrial sediments in the studied region is based on Normapolles-related species. The studied assemblage is assigned to the Oculopollis zaklinskaiae-Tetracolporopollenites (Brecolpites) globosus Zone (or Zone C) indicating a late Santonian age. Comparison of the Iharkút palynoflora with other known Upper Cretaceous palynofloras of Central Europe shows diachronous occurrence of Normapolles taxa at different geographic localities and warrants further investigation.

The ecological requirements of the amphibian fauna reflect azonal conditions controlled by the availability of water, which is in agreement with the inferred ecological conditions based on the paleobotanical investigations. The fauna is of entirely non-marine character, further supported by isotope studies, in line with our data showing that the palynological samples contain no marine forms.
\end{abstract}

Key words: palynomorphs, mesofossils, Normapolles, Santonian, Iharkút, Hungary

Addresses: E. R. Bodor: H-1117 Budapest, Pázmány P. sétány 1/C, Hungary,

H-1143 Budapest, Stefánia út. 14, Hungary, e-mail: emesebodor@gmail.com

V. Baranyi: H-1117 Budapest, Pázmány P. sétány 1/C, Hungary, e-mail: emesebodor@gmail.com, baranyi.viktoria@gmail.com

Received: September 14, 2011; accepted: January 27, 2012 


\section{Introduction}

Numerous well-preserved plant remains have been discovered in Upper Cretaceous fluvial sedimentary rocks (Csehbánya Formation) at the Iharkút vertebrate locality (Bakony Mts, Hungary) (Fig. 1). The palynoflora of Iharkút is an angiosperm-dominated assemblage, which provides a unique insight into the Normapolles group, because the palynomorphs appear together with plant mesofossils and macro remains. Normapolles-related pollen grains are important elements of the Late Cretaceous and Paleogene palynofloras. They are mainly abundant within the Normapolles floristic province (eastern North America, Europe and Asia) (Batten 1981, 1982; Batten and Christopher 1981; Zaklinskaya 1981; Schönenberger et al. 2001). The Normapolles group first appeared in the middle Cenomanian and diversified rapidly, reaching its highest diversity during the Late Cretaceous, and became extinct by the end of the Eocene (Góczán et al. 1967; Pacltová 1981; Friis 1983; Sims et al. 1999).

The possible botanical affinities of the Normapolles genera are still being discussed, but several suggestions have been put forward. It has been proposed that some of the genera are related to the modern Juglandales (Juglandaceae, Rhoipteleaceae); others may be related to the Betulales, Urticales, Casuarinales, Myricales, Myrtales, Sapindales and Santalales (Krutzsch 1959; Góczán et al. 1967; Zaklinskaya 1967, 1981; Stanley and Kedves 1975; Friis 1983; Friis 1984; Skarby 1986; Crane et al. 1996; Takahasi 1997; Sims et al. 1999; Schönenberger et al. 2001; Friis et al. 2003; Friis et al. 2006).

The presence of the different Normapolles taxa in the assemblages, with their high diversity and rapid evolution during the Late Cretaceous, makes this group stratigraphically important. In the Central European-Carpathian region, Góczán (1963, 1964) and Góczán and Siegl-Farkas (1990) proposed a palynological zonation, which was later integrated with the Tethyan nannoplankton zones by Siegl-Farkas and Wagreich (1996). The palynoflora of the Csehbánya Formation is known from borehole material (Góczán 1964; Góczán and Siegl-Farkas 1990; SieglFarkas 1993; Lantos et al. 1996) but the palynological assemblages and the plant mesofossils from the Iharkút site have not been previously investigated.

Angiosperm fruits and seeds from the Hungarian Upper Cretaceous have not been comprehensively studied so far. Some drill core samples were examined by Knobloch and Mai (1986) and by Rákosi (1991) who reported mainly Magnoliaceae carpolites and lacustrine plant macrospores. The megaspores of the Ajka Coal Formation were studied by Rákosi and Barbacka (1999-2000).

The purpose of this study is to describe the Normapolles-related pollen taxa and to compare them with the angiosperm mesofossils from the same interval, and to compare our material to that of the Knobloch Collection. We also attempt to contribute to the paleoenvironmental reconstruction of this important vertebrate locality and, based on the palynomorphs, provide a more precise stratigraphic age of the bonebed. 


\section{Geologic setting}

The vertebrate locality is exposed at the abandoned Iharkút open-pit bauxite mine near the villages of Bakonyjákó and Németbánya, in the northern part of the Bakony Mountains, in western Hungary (Fig. 1). The Csehbánya Formation (Jocha-Edelényi in Császár 1997) is a floodplain and channel deposit composed of variegated clay, silt with interbedded grey and brown sand, and sandstone beds (Bodrogi et al. 1988; Jocha-Edelényi 1988). The formation has an average thickness of $50 \mathrm{~m}$ at Iharkút. In the upper part of the section an approximately $2 \mathrm{~m}$-thick layer yielded most of the vertebrate fossils (marked as Bed 6 in Fig. 1). The boneyielding beds consist of sand, silt, and clay pebbles with fragmentary bones (Tuba et al. 2006; Ôsi and Mindszenty 2009).

Fig. 1

Sketch map of the studied locality at Iharkút

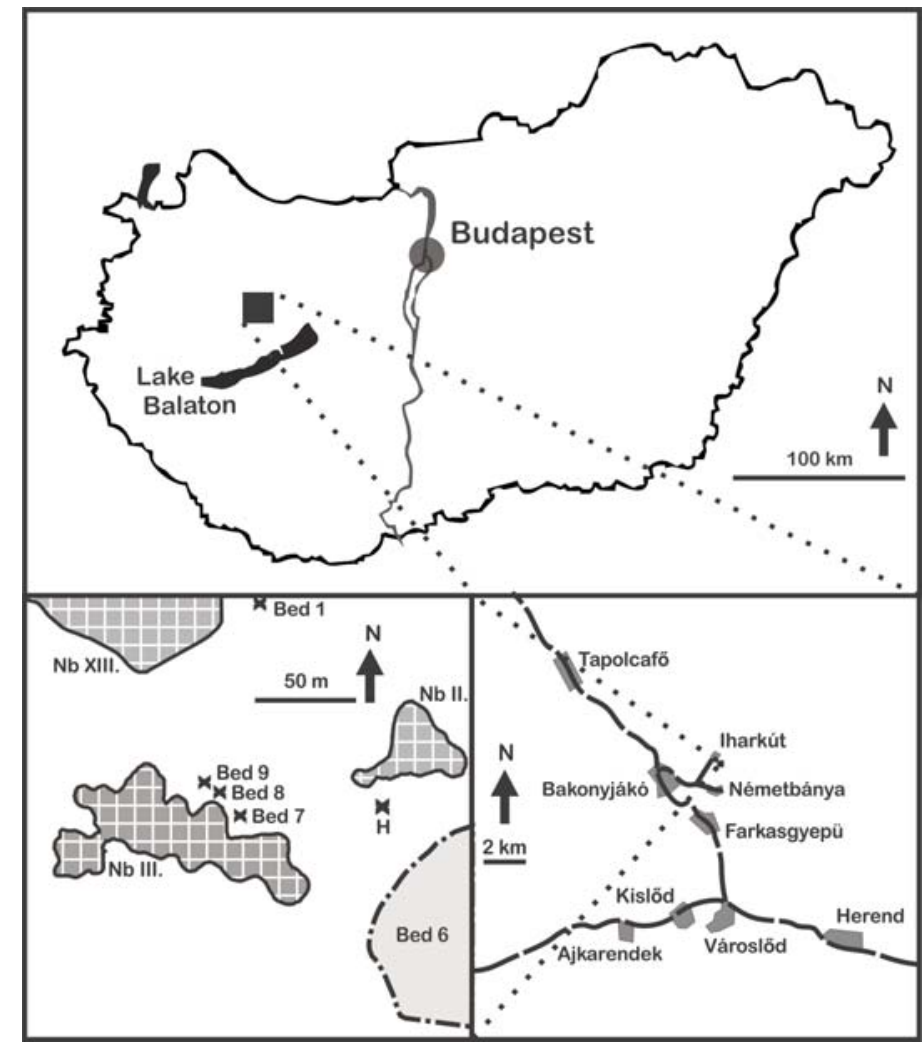

A large number of vertebrate remains were collected during the last 10 years, including thousands of fish (Makádi et al. 2006; Ôsi et al. 2012), frogs and other amphibians (Szentesi and Venczel 2010, 2012), turtles (Ősi et al. 2012; Rabi et al. 2011), lepidosaurs (Makádi 2006; Ôsi et al. 2012), crocodiles (Ősi and Rabi 2006; Ôsi et al. 2007), birds (Ősi 2008; Dyke and Ösi, in press) together with a range of bones and teeth fragments. Significantly, new dinosaur species - Hungarosaurus 
tormai (Ösi 2005), Ajkaceratops kozmai (Ósi et al. 2010) - and a new pterosaur (Bakonydraco galaczi; Ósi et al. 2005) were also described from the locality. Isotope geochemical and osteology investigation of the fossils suggests a freshwater habitat for the fauna (Kocsis et al. 2009; Makádi et al. 2012).

\section{Materials and methods}

\section{Palynomorphs}

Fifteen samples from 11 layers were analyzed in this study (Fig. 2). Processing of palynological samples was carried out at the Pollen Laboratory of the Hungarian Geological Institute in Budapest. The palynological processing involved washing of samples, acid treatment with $36 \% \mathrm{HCl}$ and $40 \% \mathrm{HF} . \mathrm{A} \mathrm{ZnCl}_{2}$ solution of $2.2 \mathrm{~g} / \mathrm{cm}^{3}$ density was used for gravity separation. Only one sample needed oxidation with $\mathrm{KOH}(30 \%)$. The residues were mounted in glycerin jelly. In total 28 palynological slides were prepared. The slides were investigated using

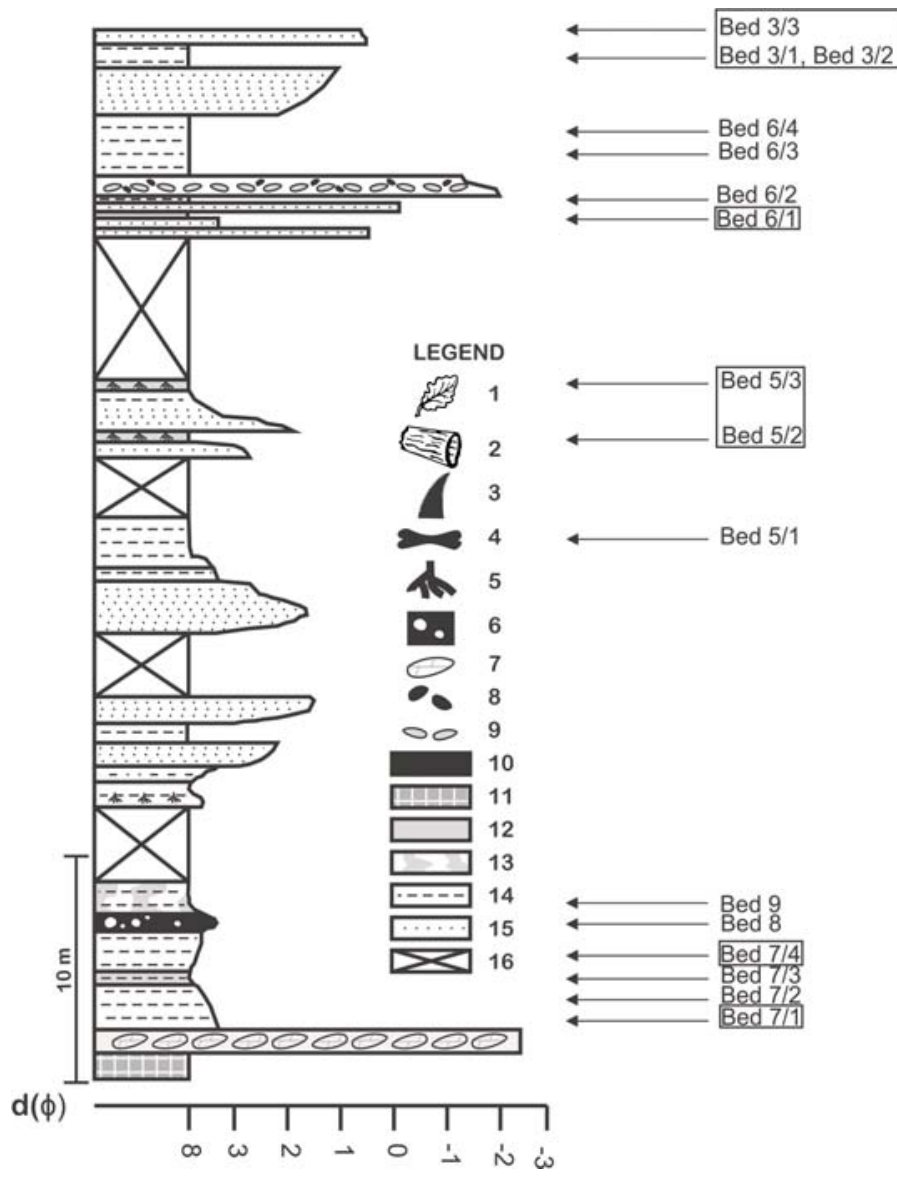

Fig. 2

Stratigraphic column of the Iharkút section with palynological sampling levels. Grain size is given in Krumbein Phi $(\phi)$ logarithmic scale, which transforms the particle diameter in millimetres by taking their negative logarithm in base 2. Legend: 1. plant macrofossils (mainly leaves); 2. tree trunks and branch fossils; 3 . teeth; 4 . bones and partial skeleton; 5. root traces; 6 amber; 7. breccia; 8 . fibrous coal; 9. mud clasts; 10 . coal; 11. bauxite; 12 . grey clay; 13 . variegated clay; 14 . clay; 15 sandstone; 16. covered part of section 
a Nikon Eclipse E600 transmitted-light microscope. Light microscope images were taken using a $40 \times$ objective and a $100 \times$ oil objective, equipped with a QImaging MicroPublisher 3.3 RTV camera. Scanning electron microscopy was carried out at the Department of Plant Anatomy, Eötvös Loránd University, using a Hitachi S-2360N microscope and at the Department of Botany, Hungarian Natural History Museum, using a S-2660N microscope. The palynological samples were mounted on aluminium stubs and sputter coated with Au-Pd using a Polaron SC7520 Mini Sputter Coater. The diversity and the absolute abundance of different palynomorph types were determined by counting 100 specimens in each slide, when it was possible. Stratigraphic diagrams were plotted using C2 software, version 1.5 (Juggins 2007).

The palynological samples are deposited in the collection of the Hungarian Natural History Museum.

\section{Mesofossils}

The fluvial clay, sand and bone-bed layers of the Csehbánya Formation yielded a diverse assemblage of small, three-dimensionally preserved angiosperm reproductive structures, including fruits and seeds. The studied mesofossils were extracted from the sediments by sieving. The dry sediment was washed at the site using $2.00 \mathrm{~mm}, 1.00 \mathrm{~mm}$ and $0.32 \mathrm{~mm}$ mesh sizes.

The bonebed (Bed 6 in Fig. 2) is the level sampled with highest resolution as it is the host rock of the vertebrate remains. The plant remains were recovered during the search for microvertebrates.

The seeds encountered in our study are black and coalified. $\mathrm{SiO}_{2}$ grains often adhere to the surface of the seeds but were removed with $40 \%$ HF. The specimens are stored in Eppendorf tubes. The unfilled specimens enabled the study of the inner structure of the seeds and fruits. Additionally, SEM studies were carried out on distinct specimens. For the mesofossil determination the material of the Knobloch Collection was used for comparison.

To study the internal structure, the fruits were oriented and placed on twosided adhesive tape. Subsequently, a $0.5 \mathrm{~cm}$-high plastic tube section was placed on the fruit. This tube was filled with a 2:1 araldite two-component epoxy-type glue mixture, dried for 24 hours, and finally polished with size 320 and size 1000 polishing powder until the middle section was reached. The section was studied using a Carl Zeiss Jena 477460 microscope. Photographs were taken with an Olympus E-500 DSLR camera.

A multivariate data analytical method, nonmetric multidimensional scaling (NMDS), was carried out on 40 whole Sphaeracostata specimens to evaluate whether the genus is represented by one or more species in our material. Dimensions, the number, trend, and surface of the ribs, reticulation of the surface, and cellular structures were entered into the data matrix. For analysis of such a mixed scale-type dataset the NMDS with Gower's formulae is the most suitable method (Podani 2001). 


\title{
Normapolles-related microfossils and mesofossils
}

Systematic palynology

The palynological assemblage is well preserved, dominated by Normapolles. Other groups such as non-Normapolles angiosperms, gymnosperms (conifers, cycads, Bennettitales), ferns and mosses formed only minor constituents of the assemblages. This study focuses on the Normapolles group. Here we describe eleven species belonging to seven genera. No marine palynomorph could be identified. In this chapter the description of the Normapolles-related key pollen taxa with their known stratigraphic range is provided. Coordinate readings from the Nikon Eclipse E600 microscope of a few examples of the studied specimens are given.

\author{
Genus Oculopollis Pflug 1953 \\ Oculopollis zaklinskaiae Góczán 1964 \\ Plate 1, figures a-b.
}

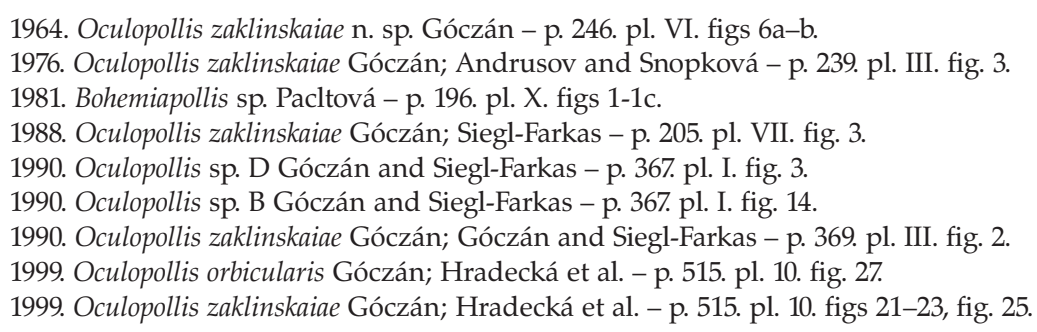

Samples and microscope coordinates: Bed 8: 95/34; 94.5/34.5; 95/39; 95/45; 96/40.5; 98.5/39; 99/31.5; 99.5/48.5; 100.5/; 103/49; 103/41; 110/43.5; 111/37; 114/39. Bed 5/1: 40/92.5; 92/23; 93/34

Material: Well-preserved, yellowish to light brown-colored pollen grains with different grades of coalification.

Dimensions: $15-20 \mu \mathrm{m}$ in diameter, excluding the length of oculi (based on 17 specimens).

Description: The pollen grain is triporate. The equatorial outline is triangular. The corpus is spheroidal to subspheroidal. The exine consists of two wall layers. No interloculum is visible between the wall layers. The nexine is much thinner than the sexine and their combined thickness is ca. $2-3 \mu \mathrm{m}$. The surface of the exine is smooth to verrucate in light microscope. The three protruding oculi are equally developed on both surfaces (on the proximal and distal side). The oculi are oval; they extend up to the center of the corpus. Size of the oculi is variable $(5-15 \mu \mathrm{m})$. Vestibulum is broad. The endanulus can be split up along the endopore.

Remarks: The Iharkút specimens above show slightly more variety in size compared to the original description but we consider them to fall within 
Oculopollis zaklinskaiae based on the germinals (oculi, anulus, oculi extend to center) and outline. The size is a less characteristic diagnostic feature of this species. Góczán (1964) described only large forms (size between $42-53 \mu \mathrm{m}$ ) as $O$. zaklinskaiae, but all of the observed specimens are slightly smaller than the holotype (53 $\mu \mathrm{m}$ in diameter). The biggest forms in the samples are characterized by large oculi (size range is $13-15 \mu \mathrm{m}$ ) and larger corpus diameter (over $20 \mu \mathrm{m}$ ). Small forms with characteristic protruding oculi occur as well. These specimens could be described as $O$. orbicularis based on the size, but the patterns of oculi, endanulus and outline differentiate them from O. orbicularis or other Oculopollis species.

Pacltová (1981) provided a photograph of a large, smooth-walled pollen grain, with large protruding oculi extending up to centre of the corpus. She described this form as Bohemiapollis sp., although according to Góczán (1964) this form is Oculopollis zaklinskaiae.

Pavlishina (1999) described O. zaklinskaiae from the lower Santonian of northern Bulgaria. On the illustration the protruding, large oculi that extend to the center of the corpus are not observable. Portniagina (1971) and Andrusov and Snopková (1976) mentioned this species from the Carpathians. The comparison is difficult in these cases because of the different microscope settings. Pavlishina et al. (2004) mentioned $O$. sp. B Góczán and Siegl-Farkas from the lower part of the upper Santonian from the Gosau Basin, but no systematic description or illustrations were presented. In the present work $O$. sp B. documented in Góczán and SieglFarkas (1990, p. 367. pl. I. fig. 14) is related to the species O. zaklinskaiae based on comparsions with those described in Góczán and Siegl-Farkas (1990).

Stratigraphic distribution: Lower Santonian of northern Bulgaria (Pavlishina 1999); lower Santonian of the Northern Calcareous Alps (Hradecká et al. 1999); Santonian of southern Bohemia (Pacltová 1977, 1981); upper Santonian of the Transdanubian Range (Góczán 1964; Siegl-Farkas 1987, 1993, 1999); Santonian lower Campanian of the Carpathians (Andrusov and Snopková 1976), lower Campanian of the Klippenbelt in the Carpathians (Portniagina 1971).

Oculopollis orbicularis Góczán 1964

Plate 1, figure c, Plate 2, figure a-c

1964. Oculopollis orbicularis n. sp. Góczán - p. 246. pl. VI. figs 1-5.

1976. Oculopollis orbicularis Góczán; Andrusov and Snopková - p. 235. pl. I. fig. 4.

1999. Oculopollis orbicularis Góczán; Siegl-Farkas - p. 185. pl. III. fig. 2.

Samples and microscope coordinates: Bed 8: 100/44. Bed 5/1: 91.5/23; 91.5/27; 92/39; 101/36.5; 104.5/35; 107/44; 110/42.5. Bed 9: 96/41.5. SEM tracer/1.

Material: Well to moderately preserved. yellowish to light brown-colored pollen grains with different grades of coalification.

Dimensions: 10-15 $\mu \mathrm{m}$ in diameter excluding the length of oculi (based on 10 specimens). 
Description: The pollen grain is triporate. The equatorial outline is triangular. The corpus is spheroidal. Size of the pollen grains is generally small (diameter $\sim 20-25 \mu \mathrm{m}$ including the length of the oculi). The exine is multilayered; interloculum is not clearly visible. Surface of the exine is granulate. The oculi are developed both on the proximal and distal side of the pollen grain. They never extend up to center of the corpus and over the equatorial outline. Their lenght is c. $5 \mu \mathrm{m}$.

Remarks: Oculopollis orbicularis is generally smaller than O. zaklinskaiae in all investigated samples and differs further in orientation and size of oculi. Oculi of $O$. orbicularis never extend up to the center and the surface of these specimens is always strongly sculptured. Surface of $O$. orbicularis is granulate, contrary to $O$. zaklinskaiae which is smooth to verrucate. Interloculum can be observed in $O$. orbicularis contrary to O. zaklinskaiae.

Stratigraphic distribution: Upper Santonian-Campanian of the Transdanubian Range, Hungary (Góczán 1964; Siegl-Farkas 1987, 1993, 1999); northeastern Spain, southern France (Médus 1972); lower Santonian-lower Campanian of northern Bulgaria (Pavlishina 1999), Santonian of the Northern Calcareous Alps (Hradecká et al. 1999; Pavlishina et al. 2004), Santonian-lower Campanian of Romania (Mogoş 1992); lower Campanian of the Klippenbelt in the Carpathians (Portniagina 1971).

\section{Oculopollis parvoculus Góczán 1964}

Plate 1, figure d

1964. Oculopollis parvoculus n. sp. Góczán - p. 246. pl. VI. fig. 9a-c.

1999. Oculopollis parvoculus Góczán; Siegl-Farkas - p. 186. pl. IV. fig. 8.

Samples and microscope coordinates: Bed 8: 94.5/42; 99/47. Bed 5/1: 109/44; 93/35; 108.5/36. Bed 9:109/53

Material: Well-preserved, yellowish, greenish to light brown-colored pollen grains with low grade of coalification.

Dimensions: $10-15 \mu \mathrm{m}$ in diameter excluding the length of oculi (based on six specimens).

Description: The pollen grain is triporate. The equatorial outline is triangular with convex sides. The inner outline is club-shaped. The exine has two layers; their combined thickness is about $2-3 \mu \mathrm{m}$. The surface of corpus is punctate. The oculi are visible on both surfaces, but they are short and not well developed. The atrium is broad. Size of the grains is variable (diameter $25-40 \mu \mathrm{m}$ including the length of the oculi).

Remarks: Oculopollis parvoculus is a transitional form between species of Oculopollis and Trudopollis (Góczán 1964). The germinal area of Trudopollis is less developed than that of $O$. parvoculus; surface ornamentation, inner contour and equatorial outline of the two forms can be very similar. Oculi of $O$. parvoculus are faintly developed. Interloculum can be observed both in O. orbicularis and in $O$. parvoculus. 
Stratigraphic distribution: Lower part of upper Santonian of the Gosau Basin, Austria (Siegl-Farkas 1994); Santonian-lower Campanian of the Carpathians (Andrusov and Snopková 1976); upper Santonian of the Transdanubian Range, Hungary (Góczán 1964; Siegl-Farkas 1987, 1993, 1999).

\title{
Laudaypollis Góczán 1964 \\ Laudaypollis clarus Góczán 1964 \\ Plate 1, figure $\mathrm{f}$
}

1964. Laudaypollis clarus n. sp. Góczán - p. 257. pl. IX. figs 17a-c.

1967. Laudaypollis clarus Góczán; Góczán et al. - p. 548. pl. IX. figs 1-5.

1988. Laudaypollis clarus Góczán; Siegl-Farkas - p. 203. pl. VI. figs 10-11.

1990. Laudaypollis sp. Góczán and Siegl-Farkas - p. 367. pl. I. figs 15-16.

Samples and microscope coordinates: Bed 5/1: 99/25; 110.5/26.5. Bed 6/3: 95/22.5

Material: Well-preserved, yellowish-light green-colored pollen grains.

Dimensions: Length is $\sim 20 \mu \mathrm{m}$ (based on two specimens).

Description: The pollen grain is diporate. The equatorial outline is bipolar, ellipsoidal. The exine is thin, less than $1 \mu \mathrm{m}$ in thickness, and the surface is punctate.

Remarks: Only two specimens were identified in the studied samples. They differ from other Normapolles genera in having two germinals, and in their bipolar, ellipsoidal shape.

Stratigraphic distribution: Santonian (Transdanubian Range, Hungary, Góczán 1964; Siegl-Farkas 1999); early Santonian of the Northern Calcareous Alps (SieglFarkas 1994).

\author{
Complexiopollis Krutzsch 1959 \\ Complexiopollis complicatus Góczán 1964 \\ Plate 1 , figure $\mathrm{g}$, Plate 2 , figure $\mathrm{e}-\mathrm{f}$
}

1964. Complexiopollis complicatus n. sp. Góczán - p. 244. pl. V. figs 8-9d.

1981. Complexiopollis sp. Pacltová - p. 188. pl. III. fig. 2.

1988. Complexiopollis complicatus Góczán; Siegl-Farkas - p. 199. pl. IV. figs 4-10.

1990. Complexiopollis complicatus Góczán; Góczán and Siegl-Farkas - p. 367. pl. I. figs 4-6., 11.

Samples and microscope coordinates: Bed 8: 94.5/39; 95/33.5; 101/34.5. Bed 5/1: 95/49; 96/49.5; 97/41; 101/41, SEM tracer 1.

Material: Well to moderately preserved, yellowish to brown pollen grains, in some cases extremely folded.

Dimensions: 10-20 $\mu \mathrm{m}$ in diameter (based on seven specimens).

Description: The pollen grain is triporate. The equatorial outline is triangular with convex to extremely concave sides. The corpus is spheroidal. The germinals are elongated and longer than the corpus diameter. The exine is multilayered. The surface of the exine is smooth to finely ornamented. Secondary folds on the 
proximal side of the pollen grain are common. The endanulus can be split up along the endopore, forming a fissure.

Remarks: They differ from the other Normapolles genera in having elongated germinals, a smoother surface and secondary exine folds. No oculi or plicae are present. C. labilis is generally larger and its sides are extremely concave. The diameter of corpus is much smaller than the length of the germinals.

Stratigraphic distribution: Santonian of the Transdanubian Range, Hungary (Góczán 1964; Siegl-Farkas 1987, 1993, 1999).

\section{Complexiopollis labilis (Góczán 1964) \\ Góczán and Krutzsch 1967 n. comb. in Góczán et al. 1967 \\ Plate 1 , figure $\mathrm{h}$}

1964. Latipollis labilis n. sp. Góczán - p. 244. pl. V. fig. 7.

Samples and microscope coordinates: Bed 5/1: 98/40, 95/32.5, 94.5/29.5

Material: Well to moderately preserved, yellowish to brown pollen grains, in some cases extremely folded.

Dimensions: $20-25 \mu \mathrm{m}$ in diameter (based on three specimens).

Description: The pollen grain is triporate. The equatorial outline is triangular with extremely concave sides. Fragile forms with elongated and narrow germinals. The surface of the exine is smooth to finely ornamented. Secondary folds on the proximal side of the pollen grain are common. The endanulus can be split up along the endopore, forming a fissure.

Remarks: It differs from Complexiopollis complicatus in having a larger size and extremely concave sides and long, narrow germinals.

Stratigraphic distribution: Santonian of the Transdanubian Range, Hungary (Góczán 1964; Siegl-Farkas 1987, 1993, 1999).

\section{Hungaropollis Góczán 1964 \\ Hungaropollis krutzschi Góczán 1964 \\ Plate 1, figure e}

1964. Hungaropollis krutzschi n. sp. Góczán - p. 251. pl. VIII. figs 4-5.

1967. Hungaropollis krutzschi Góczán; Góczán et al. - p. 546. pl. VII. figs 7-16.

1988. Hungaropollis krutzschi Góczán; Siegl-Farkas - p. 207. pl. VIII. figs 5-6.

1983. Hungaropollis krutzschi Góczán; Kedves and Diniz - p. 345. pl. 2. figs 1-3.

1988. Hungaropollis sp. Siegl-Farkas - p. 207. pl. VIII. figs 7-8.

2002. Hungaropollis krutzschi Góczán; Siegl-Farkas and Haas - p. 170. pl. II. fig. 26.

Samples and microscope coordinates: Bed 8: 95/37.5; 99/48.5; 100/44. Bed 5/1: 94/29.5; 111/35; 104/26.5; Bed 9: 109/37

Material: Well-preserved, yellowish to light brown-colored pollen grains.

Dimensions: $40-50 \mu \mathrm{m}$ in diameter (based on seven specimens). 
Description: The pollen grain is triporate. The equatorial outline is triangular with convex sides and rounded angles. The inner contour is triangular with extremely rounded angles to circular. Exine is multilayered. The sexine is very thick, the nexine is thinner; it consists of three layers. Their combined thickness can reach $6-8 \mu \mathrm{m}$ (up to $10 \mu \mathrm{m}$ in the germinal region). The vestibulum is narrow. The surface of the exine is strongly sculptured in the central region of the proximal side. The ornamentation is verrucate. On the distal side no characteristic sculpture is visible.

Remarks: Only a few specimens of this genus occurred in the studied samples. They differ from other Normapolles genera in their large size, characteristic outline and ornamentation. No oculi, plicae or secondary folds are present. Hungaropollis krutzschi and other species of the genus are well known from the Upper Cretaceous of Hungary (Góczán 1964; Góczán et al. 1967; Góczán and Siegl-Farkas 1985, 1990, 1991; Kedves and Diniz 1983; Siegl-Farkas 1988; SieglFarkas and Haas 2002). The comparison with those pollen grains is not possible as they were not illustrated by Mogoş (1992).

Stratigraphic distribution: Upper Santonian of the Transdanubian Range, Hungary (Góczán 1964; Siegl-Farkas 1988, 1993, 1999), Santonian-lower Campanian of the Borod Basin, Romania (Mogoş 1992).

\section{Schulzipollis Góczán 1967 in Góczán et al. 1967}

Schulzipollis pannonicus n. sp. Góczán 1967 in Góczán et al. 1967

Plate 1, figure i

1967. Schulzipollis pannonicus n. sp. Góczán; Góczán et al. - p. 555. pl. XVI. figs 1-12.

1988. Schulzipollis pannonicus Góczán; Siegl-Farkas - p. 203. pl. VI. figs 6-7.

1990. Schulzipollis pannonicus Góczán; Góczán and Siegl-Farkas - p. 367. pl. I. figs 17-19.

1999. Schulzipollis pannonicus Góczán; Hradecká et al. - p. 515. pl. 10. figs 16-20.

Samples and microscope coordinates: Bed 5/1: 110/36.5; 98/40

Material: Well-preserved, yellow-green-colored pollen grains with low grade of coalification.

Dimensions: $20-25 \mu \mathrm{m}$ in diameter (based on two specimens).

Description: The pollen grain is triporate. The equatorial outline is triangular with convex sides and slightly rounded angles. The exine consits of two wall layers. Interloculum is present. The surface of the exine is ornamented on both sides with granulae in varying intensity. On the proximal side a Y-shaped plica connects the three germinals over the corpus. In the germinal area there is a poorly developed annulus.

Remarks: Schulzipollis is a monospecific genus. Only two specimens were identified in the investigated samples. S. pannonicus differs from other Normapolles types in having plicae and an ornamented surface.

Stratigraphic distribution: Santonian of the Transdanubian Range, Hungary (Góczán et al. 1967); lower Santonian of the Northern Calcareous Alps (Hradecká et al. 1999; Siegl-Farkas 1994). 
Verroculopollis Kedves and Diniz 1983

Verroculopollis sp.

Plate 1, figure $\mathrm{j}$

Samples and microscope coordinates: Bed 5/1: 93/24.5; 101/40.5

Material: Moderately preserved, brown-colored pollen grains.

Dimensions: $\sim 40 \mu \mathrm{m}$ in diameter including the length of the oculi (based on two specimens).

Description: The pollen grain is triporate. The equatorial outline is triangular with convex sides. The corpus is spheroidal to subspheroidal. The exine consits of two wall layers. No interloculum is visible between the wall layers. The nexine is much thinner than the sexine; their combined thickness is about $5 \mu \mathrm{m}$ in the extragerminal region. The surface of the exine is strongly verrucate. Vestibulum is broad. The three oculi are protruding, but their length is reduced. Oculi are developed on both proximal and distal side of the pollen grain. The rims of the oculi are undulating. The oculi are oval; they do not extend up to the centre of the corpus. Size of the oculi is $15 \mu \mathrm{m}$.

Remarks: The main feature of this genus is the undulating outline of the oculi and the strongly verrucate to rugulate surface. The genus Verroculopollis includes three species: V. pflugi, V. tschudy and V. skarbyae. Both V. pflugi and V. tschudy have long, well-developed, protruding oculi. $V$. skarbyae has similar characteristics to the studied specimens with reduced oculi; however, the ornamentation of the two forms differ. The size of sculptural elements of $V$. skarbyae is larger compared to our specimens. Based exclusively on ornamentation, the studied specimens are more similiar to V. pflugi; however, the germinal area differs significantly. We have not been able to determine our specimens at the species level and thus leave it in open nomenclature.

Stratigraphic distribution: Upper Santonian of the Transdanubian Range, Hungary (Kedves and Diniz 1983).

Krutzschipollis Góczán 1967 in Góczán et al. 1967

Krutzschipollis crassus (Góczán 1964) Góczán 1967 n. comb. in Góczán et al. 1967.

Plate 1, figure 1

1964. Extratriporopollenites crassus n. sp. Góczán - p. 251. pl. VIII. figs 1-2.

1986. Krutzschipollis crassus (Góczán) Góczán; Siegl-Farkas - p. 449. pl. VI. figs 7-8

1999. Krutzschipollis crassus (Góczán) Góczán; Pavlishina - p. 201. pl. I. figs 17-19.

2002. Krutzschipollis crassus (Góczán) Góczán; Siegl-Farkas and Haas - p. 171. pl. III. fig. 19.

Samples and microscope coordinates: Bed 7/2: 108/25.5; 106/44, Bed 5/1: 108/25.5

Material: Well-preserved, brown-colored pollen grains.

Dimensions: $30-40 \mu \mathrm{m}$ in diameter (based on three specimens).

Description: The pollen grain is triporate. The equatorial outline is triangular with convex sides. The inner contour is circular. The exine is thick consisting of two wall layers of equal thickness. The exine is thickened in the germinal area to form oculus-like elements. 
No interloculum is present. The surface of the exine is verrucate-rugulate. The outer part of the germinal area is slightly elongated. The annulus is well developed. The atrium is broad.

Remarks: The surface of Krutzschipollis spatiosus is more heavily ornamented than K. crassus (Góczán et al. 1967). The oculi of Oculopollis species are more developed. The surface ornamentation is coarser compared to Hungaropollis and the germinal area is different from that of Krutzschipollis. Longanulipollis differs from Krutzschipollis in having more elongated germinals, club-shaped inner contour and its surface ornamentation can be smoother (Góczán et al. 1967).

Stratigraphic distribution: Upper Santonian-Campanian of the Transdanubian RangeTransdanubian Range, Hungary (Góczán 1964; Siegl-Farkas 1988, 1993, 1999); first occurrence is in the Lower Santonian of northern Bulgaria (Pavlishina 1999).

\section{Krutzschipollis spatiosus Góczán 1967 in Góczán et al. 1967} Plate 1 , figure $\mathrm{k}$

1967. Krutzschipollis spatiosus Góczán; Góczán et al. - p. 547. pl. VIII. figs 16-19.

1990. Krutzschipollis spatiosus Góczán; Góczán and Siegl-Farkas - p. 372. pl. V. figs 1-2.

1996. Krutzschipollis cf. spatiosus Lantos et al. - p. 115. pl. 5. fig. 5.

1999. Krutzschipollis spatiosus Góczán; Pavlishina - p. 201. pl. I. fig. 16.

Samples and microscope coordinates: Bed 5/1: 96/24.5

Material: Moderately preserved, yellowish to brown pollen grains with different grades of coalification.

Dimensions: $30-40 \mu \mathrm{m}$ (based on one specimen).

Description: The pollen grain is triporate. The equatorial outline is triangular with convex sides. The inner contour is circular. The exine is thick and consits of two wall layers of equal thickness except in the germinal area where outer wall layer is thickened. No interloculum is present. The surface of the exine is strongly ornamented with 2-6 $\mu \mathrm{m}$ long scarps.

Remarks: The surface of Krutzschipollis spatiosus is more densely ornamented compared to K. crassus. They are the largest representatives of the genus (Góczán et al. 1967).

Stratigraphic distribution: Lower Campanian of the Transdanubian Range, Hungary (Góczán 1964; Siegl-Farkas 1993, 1999); first occurrence in the middle Santonian of northern Bulgaria (Pavlishina 1999).

\section{Systematics of plant mesofossils}

On the basis of a rich assemblage of small, three dimensionally-preserved fossil angiosperm reproductive structures, two morphotypes of fruits with Normapolles affinity are described herein. 
Order and family: Incertae sedis

Genus Sphaeracostata Bodor et Baranyi, gen. nov.

Type species: Sphaeracostata barbackae Bodor et Baranyi, sp. nov.

Etymology: From the two most important morphological characters of the genus. Sphaera (Latin) refers to the spherical shape; costata (Latin) refers to the surface ribs.

Generic diagnosis: Fruit is small, spherical to ovoid, displays radial outer symmetry, possesses one seed. Surface is ribbed, base of the style has two or four branches. Inner section divided into three by the cotyledons. The cotyledons of the embryo are folded in the seed. Fruit wall is at least two-layered. Rounded, puffed cells on the pericarp. Surface cells are angular, ordered in rows.

\section{Sphaeracostata barbackae Bodor et Baranyi, sp. nov. \\ Plate 3, figures a-h}

Holotype: 2011.180

Other specimens examined: 2011.181-2011.184; 2011.191

Repository: Hungarian Natural History Museum, Department of Botany, Budapest.

Material: Well-preserved, coalified, three-dimensionally preserved fossils from sieved organic residue. Occur in variegated clay, silt, marl, grey and brown sand, and sandstone beds. The greatest number of fruits were found in the bonebed.

Type locality: Csehbánya Formation; Hungary; abandoned Iharkút open pit bauxite mine.

Stratigraphic horizon: Bed 6, a bonebed in the Santonian fluvial sequence.

Etymology: In honor of paleobotanist Dr. M. Barbacka.

Specific diagnosis: Small, spherical to ovoid fruits. The fruit is a nut. Style appears as small suture at the apical part, branching into two or four. Ovary is sickleshaped. Rounded and puffed cells, $8-12 \mu \mathrm{m}$ in diameter, form the pericarp. Conspicuous longitudinal ridges appear on the fruit surface. The fruit wall is approximately $10-50 \mu \mathrm{m}$ thick, with 5-8 $\mu \mathrm{m}$, angular surface cells, standing in parallel rows to the ribs. Cotyledons are folded.

Dimensions: Breadth: 0.9-1.2 mm (arithmetic mean $1.00 \mathrm{~mm}$ ); length: $0.8-1.3 \mathrm{~mm}$ (arithmetic mean $1.08 \mathrm{~mm}$ ); 100 complete fruits were measured.

Description: The fruit is approximately $1 \mathrm{~mm}$ wide and $1 \mathrm{~mm}$ long, rounded, longitudinally ridged on the entire surface (Plate 3, figures b, c, d, f). The number of the ribs varies between 8 and 30. Attachment scar at the base is not visible (Plate 3 , figure b). In transverse section the fruits are round or ovate. The fruit wall is up to $50 \mu \mathrm{m}$ thickness (Fig. 3). The inner structure is always divided by an endopleura; the thickness of the endopleura is usually half of the fruit wall (Plate 3 , figures $\mathrm{g}, \mathrm{h}$ ). These pleuras most likely represent the two cotyledons. The fruits show two types of morphology depending on the shape of cells on their surface. The cells of the first type are elongated and angular (Plate 3, fig. f). The other type 
is characterized by rounded cellular structures (Plate 3, fig. c). The angular cells are presumably the inner cells of the fruit coat. The rounded cells could be the outer cells of the fruit coat. Uncertainty remains due to the state of preservation.

Remarks: The existence of different morphotypes was explored using a multivariate statistical method, nonmetric multidimensional scaling (NMDS). The analysis was carried out on 40 complete specimens, and a distinction of two morphotypes was possible based on the following characters: dimension, number and trend of ribs, surface of ribs, reticulation of the surface, and cellular structures. However, the taxonomic significancce of these two morphotypes is questionable. The possibility remains that they represent different developmental stages or different preservation. The low importance of the above-mentioned characters in the taxonomy of extant taxa suggests that these two morphotypes likely belong to the same species.

The possible affinities of Sphaeracostata were evaluated. The morphological similarities with the outer surface of Spirellea Knobloch and Mai may suggest a phylogenetic relationship (Knobloch 1977), but the detailed study of the inner structure (Fig. 3 and Plate 3, figs g, h) show important differences. The Spirellea specimens are all charcoalified, small ovoid in shape; their size is usually between 0.5 and $2 \mathrm{~mm}$ and they are covered by longitudinal ribs occasionally anastomizing or intermittent to pearl-structure, and the inner part is never divided.

Microcarpolithes striatus Vangerow 1954 has a similar outer surface structure and ornamentation to Sphaeracostata; the inner structure, however, is not known, and it is a synonym of Spirellea multistriata Knobloch and Mai 1986. The lectotype of Spirellea multistriata was re-examined and an undivided inner structure was discovered that excluded a relationship to Sphaeracostata.

Microcarpolithes costatus also shows similarity to Sphaeracostata in its ribbed outer surface (Plate 3 , figs b-d, f), but it differs from our new species in always having 8 ribs dividing the fruit (Knobloch 1964). The holotype of Microcarpolithes costatus was re-examined, but the specimen had deteriorated, rendering a re-examination impossible.

Sphaeracostata shows similaties to Normapolles; thus a comparison with mesofossils belonging to the Normapolles group was necessary. Manningia Friis 1983 is triangular in cross-section, a feature never seen in the studied material. Manningia commonly has a persistent style, with a different shape and aspect ratio of the whole fruit compared to Sphaeracostata. In the case of Manningia, the style could reach one third of the total length; in Sphaeracostata this ratio is not more than one tenth (Plate 3, fig. a). In Manningia the surface is characterized by 10 longitudinal ribs. The number of ribs of Sphaeracostata shows a higher variability, from 8 to 30 (arithmetic mean 14.8, counted on 100 complete specimen). Manningia nuts always contain one seed (Friis 1983), and the folded cotyledons have never been examined. These differences are significant enough to warrant placement into separate generea. 

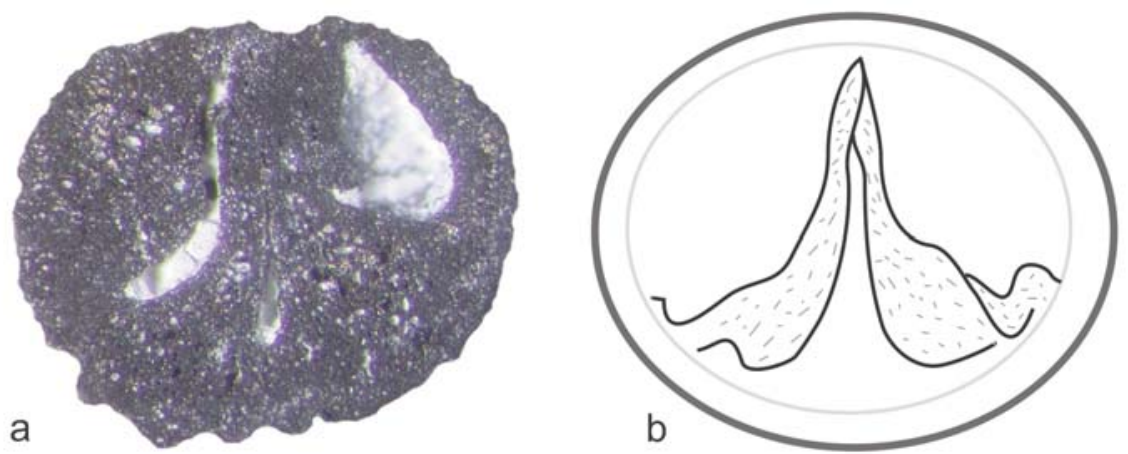

Fig. 3

a) Photomicrograph of the cross-section of Sphaeracostata barbackae sp. nov.

b) Schematic drawing of the inner section of Sphaeracostata barbackae sp. nov

The organization and structure of Calathiocarpus Knobloch et Mai is similar to that of Manningia. Calathiocarpus also differs in its inner structure from Sphaeracostata, as Calathiocarpus is never divided, whereas Sphaeracostata is always divided. The ribs of Calathiocarpus occasionally diverge; this feature has never been observed on the almost 1000 specimens of Sphaeracostata.

Antiquacarya fruits display three scars and shows actinomorph symmetry with triangular cross section. The nuts contain only one seed (Friis 1984); the cotyledons have never been observed in this genus, which rules out the possibility of it belonging to the same genus as Sphaeracostata.

The above comparison to other fossil fruits clearly necessitates the erection of a new genus and species. The proposed relationship to the Normapolles group is based on the actinomorph outer symmetry of the fruits, which is rather common in this group (Friis 1984). The folded cotyledons (Fig. 3) are characteristic of the Fagales (Karsten 1891). The divided appearence of the nuts is another typical feature in Fagales (Schimper 1908). Without establishing whether our form is gynus (hypo-, peri-, or epigynous), the taxonomical affinity could not be established more precisely. The Normapolles group is obviously not monophyletic; both epigynous and hypogynous floral organisation also occurs within it (Friis et al. 2006). The floral structures described in the Normapolles group also show several synapomorph characters with the Fagales (Friis et al. 2006). The fagalean affinity of Sphaeracostata, together with the dominance of Normapolles pollen grains in the Iharkút material, suggest the Normapolles affinity of the new genus. 


\author{
Order and family: Incertae sedis \\ cf. Caryanthus Friis 1983 \\ Plate 4, figs $\mathrm{g}, \mathrm{h}$
}

Material: 43 specimens of poorly preserved, charcoalified, fragmented, abraded, three-dimensionally preserved fruits.

Dimensions: $0.8-1.6 \mathrm{~mm}$ in length and $0.5-1.5 \mathrm{~mm}$ in breadth.

Description: Fruits are asymmetrical or bilateral. The poor preservation makes it difficult to distinguish the main taxonomical characters. The fruits have an apical split (Plate 4, figure h). The shape of the fruits is elongated or lanceolate (Plate 4, fig. g). The fruits are one-loculed. Bract is small or not detectable. Bracteoles cannot be seen in the Iharkút material. The wall structure and the testa are not noticeable. The floral part is not preserved. The lateral face of fruit is convex to concave with irregular ridges (Plate 4, fig. g). The surface is often gently and sparsely papillated. The size of papillae is less than $10 \mu \mathrm{m}$. On the damaged surface small (approx. $5 \mu \mathrm{m}$ in diameter), angular, cell-like structures are observable (Plate 4, fig. h).

Remarks: The average size of the fruits is $1.3 \mathrm{~mm}$. Some characters (one-loculed, elongate or lanceolate fruits with an apical split) indicate their relationship with the genus Caryanthus Friis.

On the studied specimens the edge of the discus is missing, as in Caryanthus multiasseris Knobloch 1986. But they also show similarities in the number and trend of the vascular bundles to some specimens of Caryanthus trebecensis Knobloch and Mai 1983. The size of the Iharkút specimens varies between the size of $C$. triaseris and C. multiasseris. In every case the bundles appear as ridges; they never exceed $50 \mu \mathrm{m}$ in thickness, commonly approximately $20 \mu \mathrm{m}$. There is a tip on some specimens, but not as big as in C. triaseris (Friis 1983; Knobloch and Mai 1983; Knobloch 1985; Knobloch and Mai 1986). It never exceeds 10\% of the fruit length. The specimens show three varieties of ornamentation. There are 8 specimens with no vascular bundles. Another 27 specimens display three distinct vascular bundles on both sides. The middle bundle does not reach the margin as in C. triaseris (Friis 1983; Knobloch and Mai 1983; Knobloch and Mai 1986). The third variety has at least three bundles, but their trend is irregular (Plate 4, fig. g), sinuous, and their number is difficult to establish as in C. multiasseris (Knobloch and Mai 1986). The poor preservation of the specimens does not allow a more precise identification.

\title{
Discussion
}

This work focuses on the Normapolles-related plant fossils that dominate the studied material, in which we identified three fruit taxa and 20 pollen taxa.

All studied samples yielded similar palynological assemblages, differing only in the abundance of different palynomorph groups (Fig. 4). Samples Bed 5/1 and Bed 8 are characterized by the highest species diversity, which is primarily the 


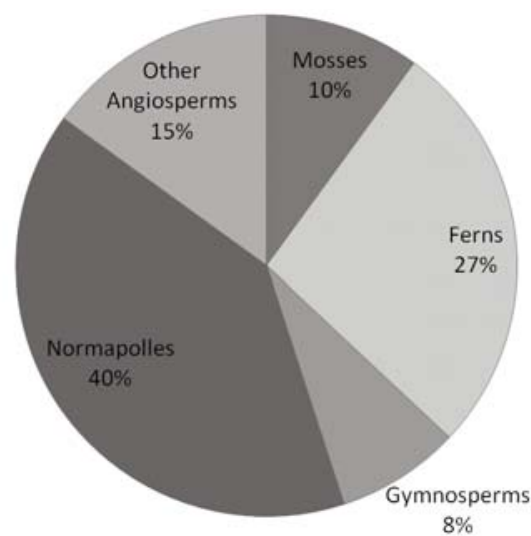

Fig. 4

Distribution of different sporomorph groups of the Iharkút assemblage

result of the very high abundance of pollen and spores in these two samples (Fig. 5). In all investigated samples the species of the genus Oculopollis dominate, particularily O. zaklinskaiae and O. orbicularis. In sample Bed 5/1 the relative abundance of Triatriopollenites coryphaeus (of Postnormapolles affinity) reaches $60 \%$ in the palynological assemblage. Tetracolporopollenites (Brecolpites) globosus (Plate 2, fig. d) also shows a high abundance in these two samples. In the uppermost layers the percentage of the species of Hungaropollis slightly increases, and the percentage of Complexiopollis decreases. Laudaypollis clarus and Schulzipollis pannonicus are extremely rare. Trudopollis, Interporopollenites and Pseudoplicapollis peneserta are common elements of the palynological assemblage. Krutzschipollis crassus and Verroculopollis sp. occur rarely.

Spores also appear in the samples, as well as few gymnosperms (Fig. 5) and dispersed cuticles of angiosperms and of Bennettitalean affinity. Angiosperm pollen grains show a much higher abundance compared to spores; however, the diversity of spore genera is comparable to that of the angiosperms. Gymnosperms (Araucaraicites australis Cookson 1947, Inaperturopollenites sp., Cycadopites sp.) are rare constituents of the palynological assemblage. In many cases the gymnosperms are reworked from older sediments (e.g. Ovalipollis sp.). No marine palynomorphs occur in the studied samples.

The studied Normapolles-related fruits are dominant in the mesofossil assemblage, representing almost $70 \%$ of the studied seeds and fruits. A new taxon is described from the mesofossil material. Sphaeracostata is represented by almost 1000 specimens. The Sphaeracostata fruits are most common in the bonebed-type layers. The other layers (Bed 7 and 8, Fig. 1) are characterized by the dominance or co-dominance of Magnoliaceae-type seeds. In addition to the fossils described here, the Iharkút material includes Sabiaceae-related fossils as well as not yet classified forms (Bodor et al. 2012). 
Palynomorphs of the Normapolles group from the Iharkút vertebrate site, Bakony Mts (Hungary) 277
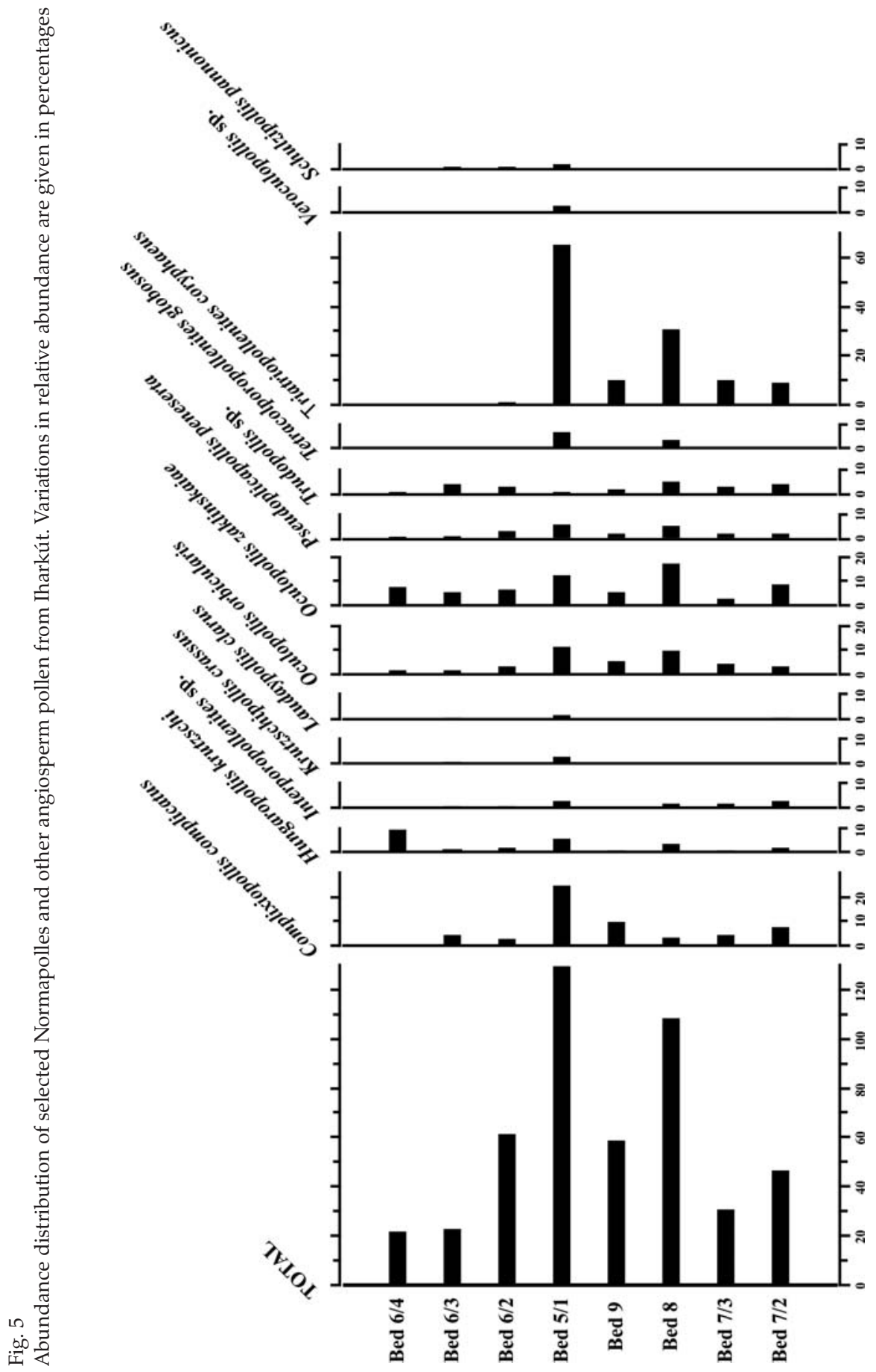

Central European Geology 55, 2012 


\section{Systematic assignment}

The microflora is in general similar to other Late Cretaceous floras of the region, with predominance of the Normapolles group. The comparison is difficult because of the inconsistency in the systematics of a few Normapolles genera, especially in the case of the genus Oculopollis. As a consequence, the agediagnostic species Oculopollis zaklinskaiae is mentioned only by relatively few authors (Góczán 1964; Siegl-Farkas 1988, 1993; Góczán and Siegl-Farkas 1990; Hradecká et al. 1999; Pavlishina 1999; Pavlishina et al. 2004).

The systematic assignment of Sphaeracostata places it within the Normapolles group. The folded cotyledon, the divided inner structure and the persistent but small stylus together suggest a possible relationship to Fagales. This morphology, according to Friis et al. (2006), suggests that a the high percentage of Normapolles plants has a fagalean affinity. Apart from the new species, Caryanthus is a wellknown genus of unquestionable Normapolles affinity at the European Upper Cretaceous localities. This relationship is beyond dispute. The fossil fruit described from Haţeg as "Taxon 1" (Lindfors et al. 2010) was also found at Iharkút (Plate 4, figs a-f), derived from an inferior ovary. Unfortunately, the maturation stage of the fruits identified in the Iharkút material does not allow to decide whether it was uni- or bisexual (Plate 4, figs a-c, f). The relation of this form to Normapolles was first suggested by Lindfors et al. (2010). This fruit is ellipsoidal (Plate 2, figs b, c, f), with forking ridges and an undivided inner structure (Plate 4, figs d, e).

Normapolles pollen grains have not been found in situ. Flowers are not common at the locality and in situ pollens are rarer in fruits. In some published cases the parent plant of some Normapolles-related pollen forms is known (Tschudi 1975; Batten and Christopher 1981; Friis 1983; Crane et al. 1989; Sims et al. 1999; Friis et al. 1999; Friis et al. 2006). From the Iharkút material, the pollen Plicapollis is known to represent the parent plant Caryanthus (Tschudi 1975; Friis 1983; Friis et al. 2009). The high percentage of Plicapollis is in contrast with the low abundance of Caryanthus in the mesofossil material. The parent plants of the dominant palynomorphs Oculopollis spp. are not yet known.

\section{Palynostratigraphy}

Based on the investigations of Góczán (1964), Góczán and Siegl-Farkas (1990) and Siegl-Farkas and Wagreich (1996) the palynological assemblage of the locality belongs to the Oculopollis zaklinskaiae-Tetracolporopollenites (Brecolpites) globosus Dominance Zone, indicating a late Santonian age of the bonebeds.

The correlation with other European palynostratigraphic schemes is not straightforward, due of the differences between the stratigraphic ranges of the dominant taxa (Fig. 6). The age-diagnostic Oculopollis group is dominant in the Santonian in Europe (Góczán 1964; Góczán et al. 1967; Portnigina 1971; Médus 1972; Andrusov and Snopková 1976; Siegl-Farkas 1988, 1993, 1999; Góczán and 
Siegl-Farkas 1990; Mogoş 1992; Siegl-Farkas and Wagreich 1996; Hradecká et al. 1999; Pavlishina 1999; Siegl-Farkas and Haas 2002; Pavlishina et al. 2004).

The dominance of Oculopollis zaklinskaiae was documented from lower Santonian strata in the lower Gosau Subgroup in Austria (Siegl-Farkas in Hradecká et al. 1999) and from Northern Bulgaria (Pavlishina 1999). However, according to the standard palynological zonation of Góczán (1964) and SieglFarkas (1999), this species clearly indicates a late Santonian age.

Oculopollis orbicularis and O. parvoculus are common in late Santonian and early Campanian palynofloras described from Hungary (Góczán 1964; Siegl-Farkas 1988; Góczán and Siegl-Farkas 1990), Spain, southern France (Médus 1972), Bulgaria (Pavlishina 1999) and the Gosau area in Austria (Siegl-Farkas 1994; SieglFarkas in Hradecká et al. 1999; Pavlishina et al. 2004). Krutzschipollis and Hungaropollis diversify during the Campanian in Hungary (Góczán 1964; SieglFarkas 1988, 1993; Siegl-Farkas and Wagreich 1996). K. spatiosus, K. crassus and Hungaropollis krutzschi dominate the early Campanian palynofloras in the Transdanubian Range (Góczán 1964; Góczán and Siegl-Farkas 1990; Siegl-Farkas 1988, 1993, 1999; Siegl-Farkas and Haas 2002). The Iharkút assemblage is characterized by a few specimens of Krutzschipollis cf. spatiosus (Siegl-Farkas, pers. com.). K. spatiosus first appeared in the middle Santonian (Pavlishina 1999). In northern Bulgaria K. crassus dominates the early Santonian palynofloras, together with Oculopollis zaklinskaiae (Pavlishina 1999).

Triatriopollenites coryphaeus, a species with Postnormapolles affinity, occurs in the early Campanian assemblages of Spain and France (Médus 1972). In constrast, in Hungary it occurs in the Santonian according to Góczán (1964) and Siegl-Farkas and Wagreich (1996), and it predominates in upper Santonian sediments in the Transdanubian Range.

This inconsistency between the ranges of the Normapolles taxa in different geographic areas makes them less valuable for biostratigraphy (Fig. 6). The known range of Oculopollis zaklinskaiae was previously restricted to the late Santonian but is here extended to the early Santonian-early Campanian. Likewise, the range of Krutzschipollis crassus, previously considered late Santonian-Campanian, is extended to the early Santonian-Campanian interval. A possible explanation is that in the study areas the paleoenvironmental changes were not synchronous, and the Normapolles-bearing plants were able to migrate to meet their ecological requirements. This was already suggested by Siegl-Farkas (1996): "the dominance zones may indicate paleoenvironments rather than ages". It is possible that similar paleoenvironments supporting a distinct type of vegetation and palynoflora developed during different times in the Central European area. Another possible explanation is the archipelago effect, proposed for continental vertebrates (Pereda-Suberbiola 2009). This effect can also control distinct vegetation distribution patterns, reflected by distinct palynofloras in the hypothesized archipelago of the Tethyan Realm. Some degree of endemism is suggested by the characteristic predominance of the species O. zaklinskaiae, and the dominance of 


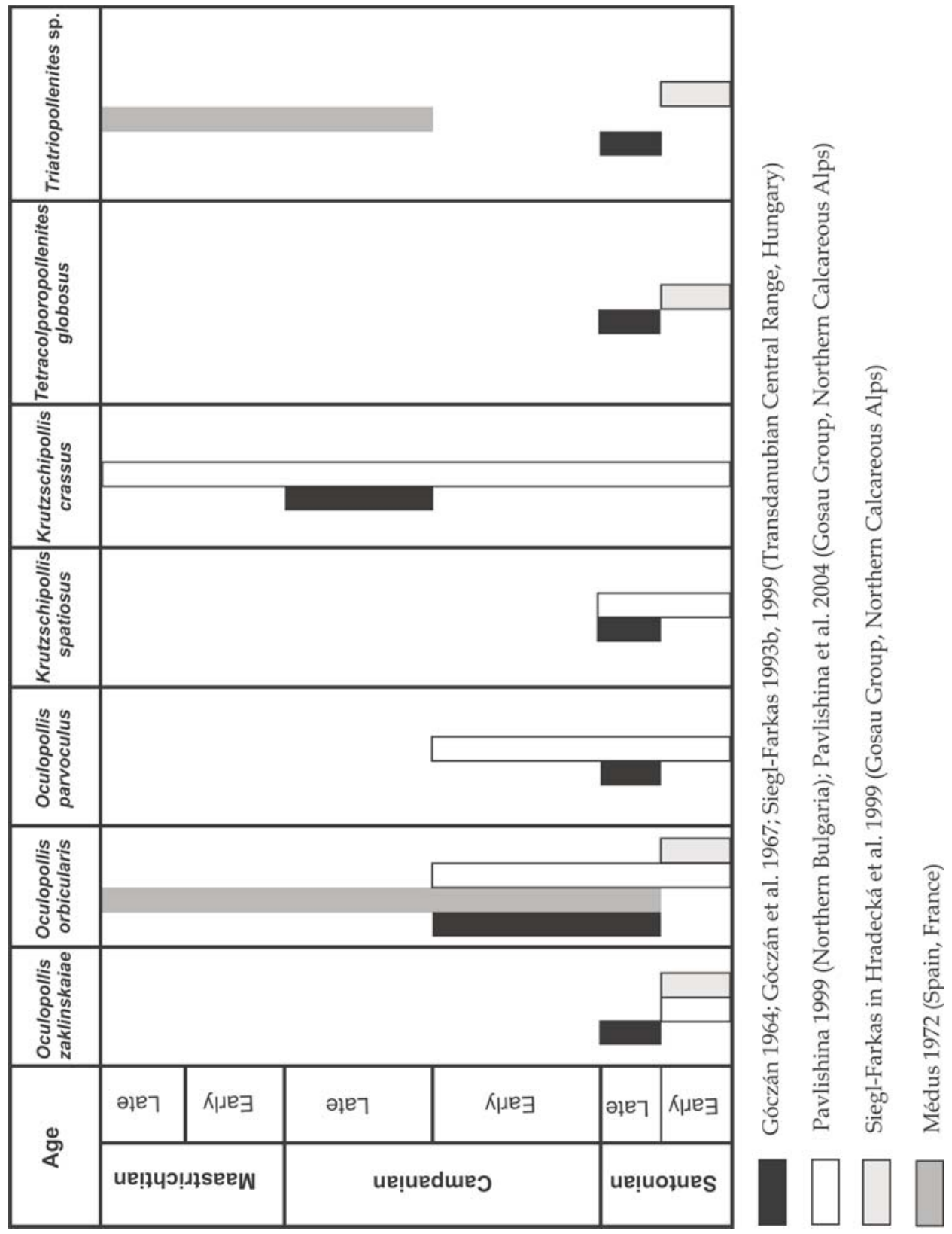

Central European Geology 55, 2012 
the genus Hungaropollis. Laudaypollis and Schulzipollis occur solely in the investigated region and in the Gosau Basin, located close to the Iharkút archipelago according to the paleogeographic reconstruction of Csontos and Vörös (2004). A complete isolation of the pollen assemblages is precluded by transport by wind, fluvial processes and currents. Wind transport is proposed to account for the mass occurrence of Normapolles taxa in the Upper Cretaceous sediments (Friis et al. 2006). Pollen assemblages reflect the regional vegetation, but each locality, e.g. each island, is characterized by specific pollen abundances.

In younger marine Upper Cretaceous sediments, the pollen zonation could be of significant biostratigraphic value (Jocha-Edelényi 1988; Lantos et al. 1996), as it is combined with biostratigraphy based on marine microfossils such as nannoplankton, plankton foraminifera and dinoflagellates (Siegl-Farkas 1997). Further work is needed to improve the zonation by correlating the terrestrial and marine records.

\section{Paleoecological reconstruction based on Normapolles-related plant remains}

The plant material described herein is incomplete and cannot be regarded as a representative assemblage. The Normapolles group is extinct and the ecological requirements of their parent plants are not known. However, the morphology of the newly described Sphaeracostata support the fagalean affinity of the majority of the Normapolles-related plants, supporting the observations of Friis et al. (2003, 2006). The dominance of these plants suggests arboraceous vegetation.

Biofacies and lithofacies indicate deposition in a fluvial environment, also suggested by the channel fill deposits in which vertebrate megafossils are abundant (Tuba et al. 2006; Ôsi and Mindszenty 2009). Paleosoil horizons further support a non-marine paleoenvironment. The differences indicate that slight but clearly identifiable paleoecological differences may exist between the sampled stratigraphic levels.

Sample Bed 8 contains abundant plant debris, resin fragments and large dispersed cuticle fragments which indicate sedimentation in a low-energy environment, probably on a flood plain or near an abandoned channel.

These environmental conditions are supported by the vertebrate paleontological data from the locality. Fluvial habitats and wet conditions were necessary for the amphibians from Iharkút. Using the methods of Böhme et al. (2006) to infer frog habitats, Szentesi and Venczel (2012) assigned Bakonybatrachus fedori to a periaquatic group whereas Hungarobatrachus represents a semiaquatic and woodland group (Szentesi pers. comm.). The most common lizards of the

$\leftarrow$ Fig. 6

Ranges of selected pollen taxa from the Transdanubian Range (Iharkút included) (Góczán 1964; Góczán et al. 1967; Siegl-Farkas 1993b, 1999), southern France and northeastern Spain (Médus 1972), northern Bulgaria (Pavlishina 1999), and the Northern Calcareous Alps (Hradecká et al. 1999; Pavlishina 2004) 
locality are the scincomorphs (Makádi 2006). Some well-preserved specimens belong to Bicuspidon. Most skinks are members of the heliophile ecophysiologic group and some of them belong to the subterranean arboreal group (Böhme et al. 2006). Crocodiles belong to the obligate aquatic ecophysiologic group, and their modern representatives live in subtropical and tropical climate. Turtles are also very common at the fossil site (Rabi et al. 2011); they belong to the periaquatic, semiaquatic and obligate aquatic groups (Böhme et al. 2006). Closer environmental determination has not yet been possible. The environmental requirements of the other vertebrate groups known from the locality are not well known (Ősi et al. 2012). In summary, the vertebrate-based paleoecological inferences are in accordance with the paleobotanical evidence. The Normapollesrelated plants appear to be members of arboreal vegetation, but the presence of other seeds, fruits and palinomorphs at the locality suggest that the forest was not completely closed. The heliophile skinks were able to live in these glades. Abundance of water for animals of high water demand was provided by a nearby fluvial system.

\section{Conclusions}

The palynoflora and mesoflora of Iharkút provide information on the age and composition of the vegetation of this rich and diverse vertebrate locality. Palynostratigraphy allows assigning the bonebed to the Oculopollis zaklinskaiaeTetracolporopollenites (Brecolpites) globosus Dominance Zone of the standard palynological zonation of Góczán (1964) and Góczán and Siegl-Farkas (1990), indicating a Santonian age. Based on the new data, including the dominant Normapolles species, the precise age is probably early-middle Santonian, on the basis of the occurrence of Oculopollis zaklinskaiae and Tetracolporopollenites (Brecolpites) globosus in lower Santonian sediments of the Gosau Basin (Austria). These results provide an improved stratigraphical resolution for the sampled interval.

Our study of the Iharkút mesofossils have led to the erection of a new angiosperm fruit genus and species, based on almost 1000 specimens. With remarkable preservation of the inner structure, the morphology of the newly described genus supports the fagalean affinity of similar Normapolles-related fossils. The fagalean affinity of these plants indicates an aboraceous vegetation at the Iharkút site.

The paleogeographic reconstruction of the Late Cretaceous archipelago of this region suggests that local environmental variations may have controlled the differences between palynological assemblages, highlighting the significance of the mesofossils for vegetation reconstruction. 


\section{Acknowledgements}

We thank Zuzana Herminová and Jiri Kvaček for the opportunity to study the Knobloch Collection. We also thank Maria Barbacka, Annette E. Götz, Ágnes Görög, Ágnes Siegl-Farkas, József Pálfy, Miklós Kázmér and Attila Ốsi who contributed to the research. Thanks are also extended to Krisztina Buckó and Károly Bóka for the technical help during the SEM studies. Zoltán Szentesi helped in mesofossil preparation; Attila Virág assisted in the preparation of figures. Our studies were supported by the entire team of the Hungarian Dinosaur Expedition, all members of the Department of Botany, Hungarian Natural History Museum, especially Lilla Hably and all members of the Department of Palaeontology, Eötvös Loránd University. Geovolán Ltd. and MAL Ltd. supported the field work. Constructive reviews by Mihai Popa and Vivi Vajda led to an improved manuscript. This work was financially supported by the Hantken Foundation, OTKA PD 73021, NF 84193 and the TAMOP 4.2.1./B09/KMR-2010-0003 project funded by the European Union and the European Social Fund. Viktória Baranyi is supported by the Student Scholarship of the AASP-The Palynological Society.

\section{References}

Andrusov, D., P. Snopková 1976: Trouvaille d'une palynoflore Sénonienne dans le Membre A Conglomérats Rouges de Dobšinska Jadová Jaskyna (Slovaquie Centrale). - Geologica Carpathica, 27, pp. 231-245.

Batten, D.J. 1981: Stratigraphic, palaeogeographic and evolutionary significance of Late Cretaceous and Early Tertiary Normapolles pollen. - Review of Palaeobotany and Palynology, 35, pp 125-137.

Batten, D.J. 1982: Note on the European-Turonian part of the Normapolles province. - Review of Palaeobotany and Palynology, 36, pp. 379-380.

Batten, D.J., R.A. Christopher 1981: Key to the recognition of Normapolles and some morphologically similar pollen genera. - Review of Palaeobotany and Palynology, 35, pp. 359-383.

Bodor, E.R., V. Baranyi, Z. Hermanová 2012: The earliest Sabiaceae fruit remains of Hungary. Hantkeniana, 7, pp. 11-18.

Bodrogi, I., A. Fogarasi, E.A. Yazikova, O. Sztanó, M. Báldi-Beke 1998: Upper Cretaceous of the Bakony Mts. (Hungary): sedimentology, biostratigraphy, correlation. - Zbl. Geol. Paläont. Teil I, 11/12, pp. 1179-1194.

Böhme, M., A. Ilg, A. Ossig, H. Küchenhoff 2006: A new method to estimate paleoprecipitation using fossil amphibians and reptiles and the Middle and Late Miocene precipitation gradients in Europe. - Geology, 34, pp. 425-428.

Crane, P.R., P.S. Herendeen 1996: Cretaceous floras containing angiosperm flowers and fruits from eastern North America. - Review of Palaeobotany and Palynology, 90, pp. 319-337.

Crane, P.R., J.A. Doyle, M.J. Donoghue, E.M. Friis 1989: Angiosperm origins. - Nature, 342, 131 p.

Csontos, L., A. Vörös 2004: Mesozoic plate tectonic reconstruction of the Carpathian region. Palaeogeography, Palaeoclimatology, Palaeoecology, 210, pp. 1-56.

Dyke, G., A. Ösi Late Cretaceous birds from Hungary: implications for avian biogeography at the close of the Mesozoic. - Geological Journal. (In press.)

Friis, E.M. 1983: Upper Cretaceous (Senonian) floral structures of Juglandalean affinity containing Normapolles pollen. - Review of Palaeobotany and Palynology, 39, pp. 161-188. 
Friis, E.M. 1984: Preliminary report of Upper Cretaceous angiosperm reproductive organs from Sweden and their level of organization. - Annals of the Missouri Botanical Garden, 71, pp. $403-418$.

Friis, E.M., K. Raunsgaard Pedersen, P.R. Crane 1999: Early Angiosperm diversification: the diversity of pollen associated with Angiosperm reproductive structures in Early Cretaceous floras from Portugal. - Ann. Missouri Bot. Gard., 86, pp. 259-296.

Friis, E.M., K. Raunsgaard Pedersen, J. Schönenberger 2003: Endressianthus, a new Normapollesproducing plant genus of Fagalean affinity from the Late Cretaceous of Portugal. - Int. J. Plant Sci., 164, pp. 201-223.

Friis, E.M., K. Raunsgaard Pedersen, J. Schönenberger 2006: Normapolles plants: a prominent component of the Cretaceous rosid diversification. - Plant Systematics and Evolution, 260, pp. $107-140$.

Góczán, F. 1963: Outlines of the Upper Cretaceous floral evolution in the Bakony Mts. - A M. Áll. Földtani Intézet Évi Jelentése Az 1963. Évről, pp. 85-93. (In Hungarian.)

Góczán, F. 1964: Stratigraphic palynology of the Hungarian Upper Cretaceous. - Acta Geologica Hungarica, 8, pp. 229-264.

Góczán, F., Á. Siegl-Farkas 1990: Palynostratigraphical zonation of Senonian sediments in Hungary. Review of Palaeobotany and Palynology, 66, pp. 361-377.

Góczán, F., J.J. Groot, W. Krutzsch, B. Pacltová 1967: Die Gattungen des „Stemma Normapolles Pflug 1953b" (Angiospermae) Neubeschreibung und Revision europäischer Formen (Oberkreide bis Eozän). - Paläontologische Abhandlungen Abteilung B, II, 3, pp. 427-633.

Hradecká, L., H. Lobitzer, F. Ottner, R.F. Sachsenhofer, Á. Siegl-Farkas, L. Švábenická, I. Zorn 1999: Biostratigraphy and paleoenvironment of the marly transgression of Weißenbachalm Lower Gosau-Subgroup (Upper Turonian-Lower Santonian Grabenbach-Formation, Northern Calcareous Alps, Styria). - Abhandlungen der Geologischen Bundesanstalt, 56/2, pp. 475-517.

Jocha-Edelényi, E. 1988: History of evolution of the Upper Cretaceous Basin in the Bakony Mts. at the time of formation of the terrestrial Csehbánya Formation. - Acta Geologica Hungarica, 31/1-2, pp. 19-31.

Jocha-Edelényi, E. 1997: Csehbánya Formation. - In: Császár, G. (Ed.) Basic litostratigraphic units of Hungary. Charts and short descriptions. - The Geological Institute of Hungary, Budapest, $114 \mathrm{p}$.

Juggins. S. 2007: C2 Version 1.5 User guide. Software for ecological and palaeoecological data analysis and visualisation. - Newcastle University, Newcastle upon Tyne, UK. 73 p.

Karsten, H. 1891: Abbildungen zur Deutschen flora. - R. Friedlander und Sohn. Berlin. 224 p.

Kedves, M., F. Diniz 1983: Les Normapolles du Crétacé Supérieur en Europe: implication paléobiogéographiques. - Geobios, 16, pp. 329-345.

Knobloch, E. 1964: Neue Pflanzenfunde aus dem südböhmischen Senon. - Jahrbuch des Staatlichen Museums für Mineralogie und Geologie zu Dresden, 133-201.

Knobloch, E. 1977: Paläokarpologische Charakteristik der Flyschzone der mährischen Karpaten.Palaeontologie, 19, pp. 79-135.

Knobloch, E. 1985: Paläobotanisch-biostratigraphische Charakteristik der Klikov-Schichtenfolge (Oberturon - Santon) in Südböhmen. - Sborník Geologických Vyd, Geologie, 40, pp. 101-145.

Knobloch, E., D.H. Mai 1983: Carbonized seeds and fruits from the Cretaceous of Bohemia and Moravia and their stratigraphical significance. - Knihovnicka Zemný ’ho Plynu a Nafty, 4, pp. 305-332.

Knobloch, E., D.H. Mai 1984: Neue Gattungen nach Früchten und Samen aus dem Cenoman bis Maastricht (Kreide) von Mitteleuropa. - Feddes Repertorium 95, pp. 3-41.

Knobloch, E., D.H. Mai 1986: Monographie der Früchte und Samen in der Kreide von Mitteleuropa. Praha: Vydal Ústøední ústav geologicky v Academii, nakladatelství Ceskoslovenské akademie vyd, $218 \mathrm{p}$.

Kocsis, L., A. Ôsi, T. Vennemann, C.N. Trueman, M.R. Palmer 2009: Geochemical study of vertebrate fossils from the Upper Cretaceous (Santonian) Csehbánya Formation (Hungary): Evidence for a 
freshwater habitat of mosasaurs and pycnodont fish. - Palaeogeography, Palaeoclimatology, Palaeoecology, 280, pp. 532-542.

Krutsch, W. 1959: Einige neue Formgattungen und -arten von Sporen und Pollen aus der mitteleuropäischen Oberkreide und dem Tertiär. - Palaeontographica Abteilung B, 105, pp. 125-157.

Lantos, M., M. Wagreich, Á. Siegl-Farkas, E. Bodnár, G. Császár 1996: Integrated stratigraphic correlation of the Upper Cretaceous sequences in the borehole Bakonyjákó 528. - ADVANCES in Austrian-Hungarian Joint Geological Research, Budapest, pp. 97-117.

Lindfors, S.M., Z. Csiki, D. Grigorescu, E.M. Friis 2010: Preliminary account on plant mesofossils from the Maastrichtian Budurone microvertebrate site of Haţeg Basin, Romania. - Palaeogeography, Palaeoclimatology, Palaeoecology, 293, pp. 353-359.

Makádi, L. 2006: Bicuspidon aff. hatzegiensis (Squamata: Scincomorpha: Teiidae) from the Upper Cretaceous Csehbánya Formation (Hungary, Bakony Mts). - Acta Geologica Hungarica, 49, pp. 373-385.

Makádi, L., G. Botfalvai, A. Ősi 2006; Késô-kréta kontinentális gerinces fauna a Bakonyből I: halak, kétéltúek, teknôsök, gyíkok (The Late Cretaceous continental vertebrate fauna from the Bakony Mountains I: fishes, amphibians, turtles, squamates). - Földtani közlöny, 136, pp. 1-25. (In Hungarian.)

Makádi, L., M.W. Caldwell, A. Ősi 2012: The First Freshwater Mesosaurid (Upper Cretaceous, Hungary) and a New Clade of Basal Mosasauroids.- PLoS ONE, 7, pp. 1-16.

Médus, J. 1972: Palynological zonation of the Upper Cretaceous in Southern France and Northeastern Spain. - Review of Palaeobotany and Palynology, 14, pp. 287-295.

Mogoş, A.P. 1992: Palynology of an Upper Cretaceous section in the Borod Basin (north-west Romania). - Cretaceous Research, 13, pp. 325-330.

Ősi, A. 2005: Hungarosaurus tormai, a new ankylosaur (Dinosauria) from the Upper Cretaceous of Hungary. - Journal of Vertebrate Paleontology, 25, pp. 370-383.

Ósi, A. 2008: Enantiornithine bird remains from the Late Cretaceous of Hungary. - Oryctos, 7, pp. $55-60$.

Ősi, A., A. Mindszenty 2009: Iharkút, Dinosaur-bearing alluvial complex of the Csehbánya Formation. - Cretaceous sediments of the Transdanubian Central Range, Field guide of the geological excursion organized by the Sedimentological Subcommission of the Hungarian Academy of Sciences and the Hungarian Geological Society, 14-16 May 2009, Field guide, pp. 51-62.

Ősi, A., M. Rabi 2006: Egy késő-kréta kontinentális gerinces fauna a Bakonyból: krokodilok, dinoszauruszok, pteroszauruszok és madarak (The Late Cretaceous continental vertebrate fauna from the Bakony Mountains II: crocodiles, dinosaurs (Theropoda, Aves, Ornithischia), pterosaurs). - Földtani Közlöny, 136, pp. 503-526. (In Hungarian.)

Ôsi, A., D.B. Weishampel, C.M. Jianu 2005: An azhdarchid pterosaur from the Late Cretaceous of Hungary. - Acta Paleontologica Polonica, 50/4, pp. 777-787.

Ősi, A., J.M. Clark, D.B. Weishampel 2007: First report on a new basal eusuchian crocodyliform with multi-cusped teeth from the Upper Cretaceous (Santonian) of Hungary. - Neues Jahrbuch für Geologie und Paleontologie, 243/2, pp. 169-177.

Ősi, A., R.J. Butler, D.B. Weishampel 2010: A Late Cretaceous ceratopsian dinosaur from Europe with Asian affinities - Nature, 465, pp. 466-468.

Ősi, A., L. Makádi, M. Rabi, Z. Szentesi, G. Botfalvai, P. Gulyás 2012: The Late Cretaceous continental vertebrate fauna from Iharkút, western Hungary: a review. Tribute to Charles Darwin and Bernissart Iguanodons: - In: Farlow, J. (Ed.): New perspectives on Vertebrate Evolution and Early Cretaceous Ecosystems, Life of the Past, Indiana University Press.

Pacltová, B. 1977: Cretaceous Angiosperms of Bohemia - Central Europe. - The Botanical Review, 43/1, pp. 128-141.

Pacltová, B. 1981: The evolution and distribution of Normapolles pollen during the Cenophytic. Review of Palaeobotany and Palynology, 35, pp. 175-208. 
Pavlishina, P. 1999: Palynology of three Santonian-Campanian sections in Northern Bulgaria. Geologica Carpathica, 50, 2, pp. 199-202.

Pavlishina, P., R. Verreussel, H. Leerveld, H. Summesberger, M. Wagreich 2004: Palynological study of Gosau group deposits (Upper Cretaceous) of the Northern Calcareous Alps (Austria). - Ann. Naturhist. Mus. Wien, 106, pp. 67-90.

Pereda-Suberbiola, X. 2009: Biogeographical affinities of Late Cretaceous continental tetrapods of Europe: a review. - Bulletin of Geological Society of France, 180, pp. 57-71.

Podani, J. 2001: Syntax 2000. Computer program for data analysis in ecology and systematics. User's manual. - Scientia Publishing, Budapest.

Portniagina, L.A. 1971: Stratigraphy and palynology of the Upper Cretaceous-Paleogene Flysch of the Skale Zone of the Carpathians. - Review of Palaeobotany and Palynology, 11, pp. 55-64.

Rabi, M., H. Tong, G. Botfalvai 2011: A new species of the side-necked turtle Foxemys (Pelomedusoides: Bothremydidae) from the Late Cretaceous of Hungary and the historical biogeography of the Bothremydini. - Geological Magazine, 149, pp. 662-674.

Rákosi, L. 1991: Paleokarpológiai vizsgálatok a Magyarországi Krétából és Harmadkorból (Paleocarpological studies of the hungarian Cretaceous and Tertiary). - Discussiones Palaeontologicae, 36-37, pp. 127-133. (In Hungarian.)

Rákosi, L., M. Barbacka 1999-2000: Upper Cretaceous flora from Ajka (W Hungary). I. Thallophyta. Studia Botanica Hungarica, 30-31, pp. 27-55.

Schimper, W.Ph. 1874: Traité de paléontologie végétale. III. - J.B. Baillière et fils, Paris, 896 p.

Schönenberger, J., E.M. Friis, M.L. Matthews, P.K. Endress 2001: Cunoniaceae in the Cretaceous of Europe: evidence from fossil flowers. - Annals of Botany, 88, pp. 423-437.

Siegl-Farkas, Á. 1985: Palynostratigraphy of the Senonian in the Zalagyömrő-Gyepúkaján area W Hungary. - MÁFI Évi Jelentése az 1983. évrôl, pp. 213-218. (In Hungarian.)

Siegl-Farkas, Á. 1986: Palynostratigraphy of the Senonian from borehole Bácsalmás-1 (S Great Hungarian plain). - MÁFI Évi Jelentése az 1984. évrôl, pp. 425-460. (In Hungarian.)

Siegl-Farkas, Á. 1987: Palynozones in the Senonian of borehole Zalaszentlászló Zl. 1 and Zl. 3. - MÁFI Évi Jelentése az 1985. évről, pp. 433-448. (In Hungarian.)

Siegl-Farkas, Á. 1988: Palynostratigraphy and evolution history of the Ajka Coal Formation, W Hungary. - MÁFI Évi Jelentése az 1986. évről, pp. 179-210. (In Hungarian.)

Siegl-Farkas, Á. 1991: Bauxite deposits and Senonian formations in Hungary (Palynological analysis). - Acta Geologica Hungarica, 34/4, pp. 345-350.

Siegl-Farkas, Á. 1993: Palynostratigraphy of the Upper Cretaceous in Hungary. - Cretaceous Research, 14, 663-668.

Siegl-Farkas, Á. 1994: Palynologische Untersuchungen an ausgewählten Vorkommen der Gosauschichten Österreichs. - In: Lobitzer, H., G. Császár, A. Daurer (Eds): Jubiläumsschrift 20 Jahre Geologische Zusammenarbeit Österreich-Ungarn. Wien, pp. 107-122.

Siegl-Farkas, Á. 1997: Dinoflagellate stratigraphy of the Senonian formations of the Transdanubian Range. - Acta Geologica Hungarica, 40/1, pp. 73-100.

Siegl-Farkas, Á. 1999: Comparative palynology of the Senonian Formations in the Pelso and Tisza Units (Hungary). - Acta Palaeobot. Suppl. 2, pp. 195-198.

Siegl-Farkas, Á., J. Haas 2002: Stratigraphic and sedimentological analysis of the Upper Cretaceous sequence of the Zala Basin on the basis of the investigation of the Szilvágy-33 well. - Acta Geologica Hungarica, 45/2, pp. 153-174.

Siegl-Farkas, Á., M. Wagreich 1996: Correlation of palyno- (spores, pollen, dinoflagellates) and calcareous nannofossil zones in the Late Cretaceous of the Northern Calcareous Alps (Austria) and the Transdanubian Central Range (Hungary). - ADVANCES in Austrian-Hungarian Joint Geological Research, Budapest, pp. 127-135.

Sims, H. J., P.S. Herendeen, R. Lupia, R.A. Christopher, P.R. Crane 1999: Fossil flowers with Normapolles pollen from the Upper Cretaceous of southeastern North America. - Review of Palaeobotany and Palynology, 106, pp. 131-151. 
Skarby, A. 1986: Normapolles anthers from the Upper Cretaceous of southern Sweden. - Review of Palaeobotany and Palynology, 46, pp. 235-256.

Stanley, E.A., M. Kedves 1975: Electronmicroscopical investigations of the Normapolles group and some other selected European and North American angiosperm pollen I. - Pollen et Spores, 17, pp. 233-271.

Szentesi, Z., M. Venczel 2010: An advanced anuran from the Late Cretaceous (Santonian) of Hungary. - Neues Jahrbuch für Geologie und Paläontologie - Abhandlungen, 256, pp. 291-302.

Szentesi, Z., M. Venczel 2012: A new discoglossid frog from the Upper Cretaceous (Santonian) of Hungary. - Cretaceous Research, 34, pp. 327-333.

Takahashi, M. 1997: Fossil spores and pollen grains of Cretaceous (Upper Campanian) from Sakhalin, Russia. - Journal of Plant Research, 110/1098, pp. 283-298.

Tschudy, R.H. 1975: Normapolles pollen from the Mississippi embayment. - U.S. Geological Survey Prof. Paper, 865. pp. 1-42.

Tuba, Gy., P. Kiss, M. Pósfai, A., Mindszenty. 2006: Preliminary data on the diagenesis of Cretaceous bones from the Bakony Mts, Hungary. - Földtani Közlöny, 136/1, pp. 1-24. (In Hungarian.)

Zaklinskaya, E.D. 1967: Palynological studies on Late Cretaceous-Paleogene floral history and stratigraphy. - Review of Palaeobotany and Palynology, 2, pp. 141-146.

Zaklinskaya, E.D. 1981: Phylogeny and classification of the Normapolles. - Review of Palaeobotany and Palynology, 35, pp. 139-147. 


\section{Plate 1}

Scale in fig. a applies to all.

a: Oculopollis zaklinskaiae Góczán 1964, Bed 5/1, [40/92,5]

b: Oculopollis zaklinskaiae Góczán 1964, Bed 5/1, [92/23]

c-d: Oculopollis orbicularis Góczán 1964, Bed 5/1, [91,5/23]

e: Hungaropollis krutzschi Góczán 1964, Bed 9, [109/37]

f: Laudaypollis clarus Góczán 1964, Bed 5/1, [99/25]

g: Complexiopollis complicatus Góczán 1964, Bed 5/1, [95/49]

h: Complexiopollis labilis (Góczán 1964) Góczán and Krutzsch, 1967, Bed 5/1, [98/40]

i: Schulzipollis pannonicus Góczán 1967, Bed 5/1, [110/36,5]

j: Verroculopollis sp., Bed 5/1, [93/24,5]

k: Krutzschipollis spatiosus Góczán 1967 in Góczán et al., 1967, Bed 5/1, [96/24,5]

1: Krutzschipollis crassus (Góczán 1964) Góczán, 1967, Bed 5/1, [108/25,5]

\section{Plate 2}

a, b, c: Oculopollis orbicularis Góczán 1964, SEM/1

d: Tetracolporopollenites (Brecolpites) globosus Góczán, 1964, SEM/1.

e, f: Complexiopollis complicatus Góczán 1964, SEM/1.

\section{Plate 3}

Sphaeracostata barbackae sp. nov.

a: Micropilar region

b, c, d, f: Plan view of entire fruit

$\mathrm{e}, \mathrm{g}, \mathrm{h}$ : Inner wall structure

\section{Plate 4}

a-f: Unnamed form, "Taxon 1" of Lindfors et al. (2010)

a: Micropilar region.

b, c, f: plan view.

$\mathrm{d}$ : Inner structure.

e: Inner wall structure.

g: cf. Caryanthus, plan view

h: Apical split of cf. Caryanthus 
Plate 1
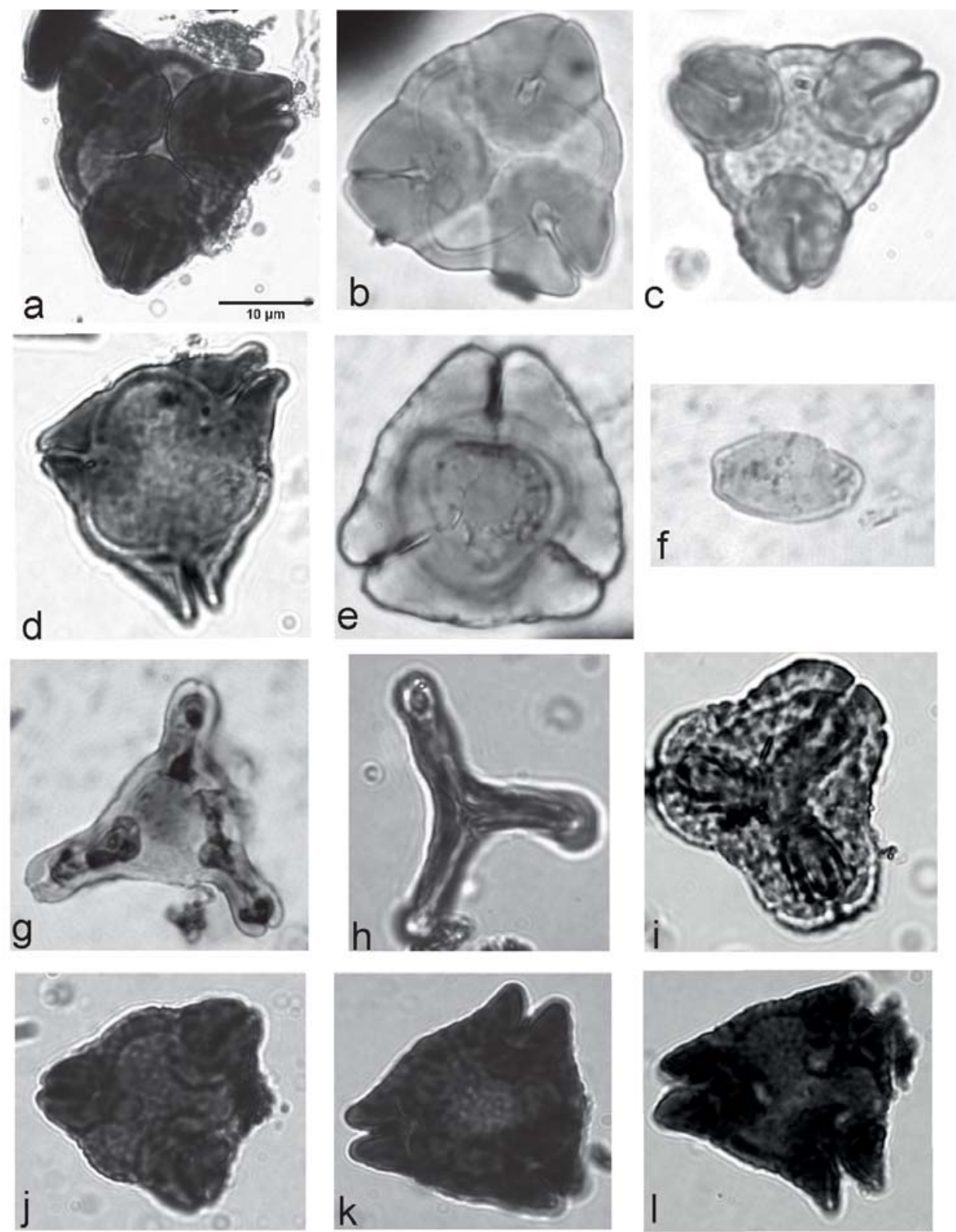

Central European Geology 55, 2012 
Plate 2
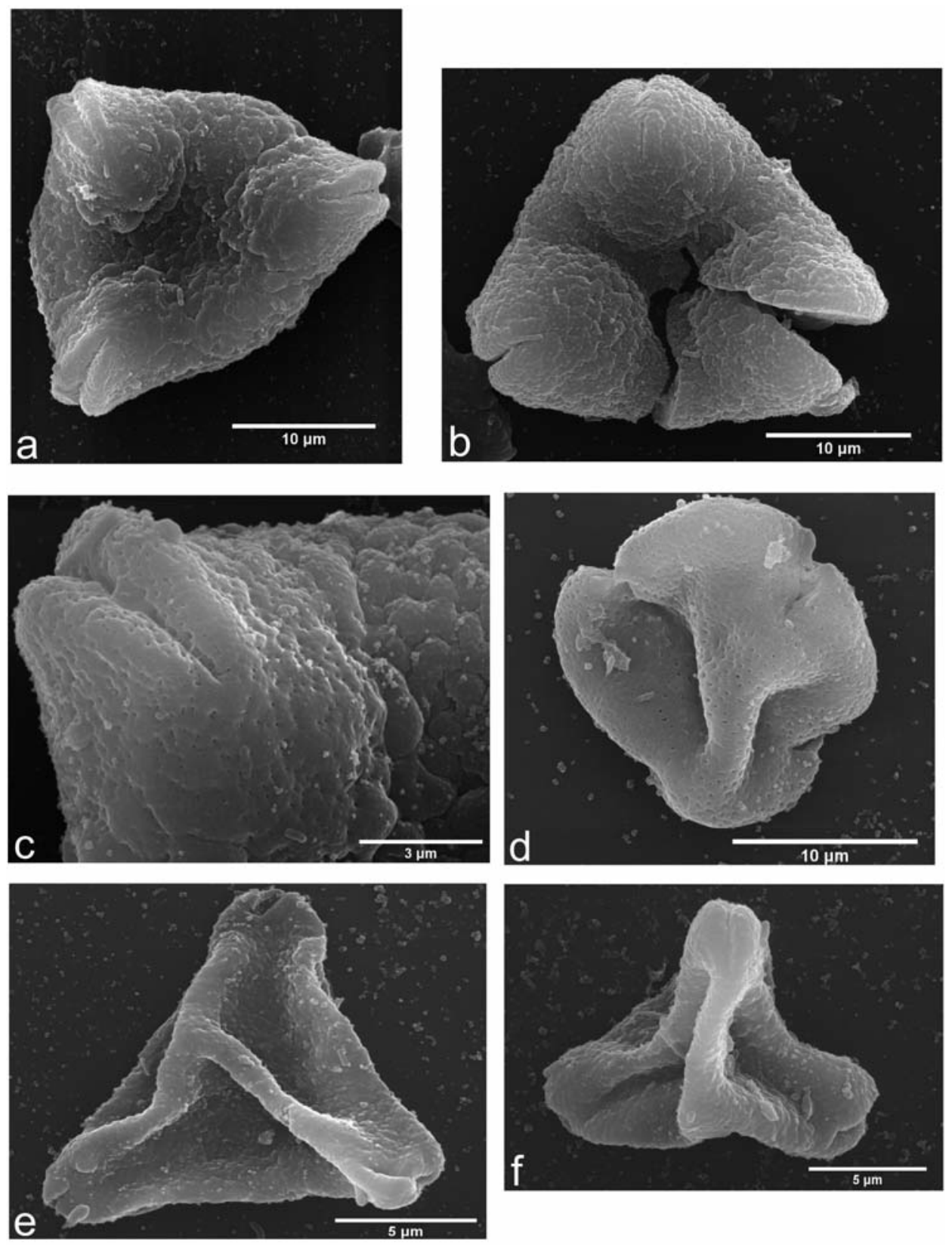

Central European Geology 55, 2012 


\section{Plate 3}

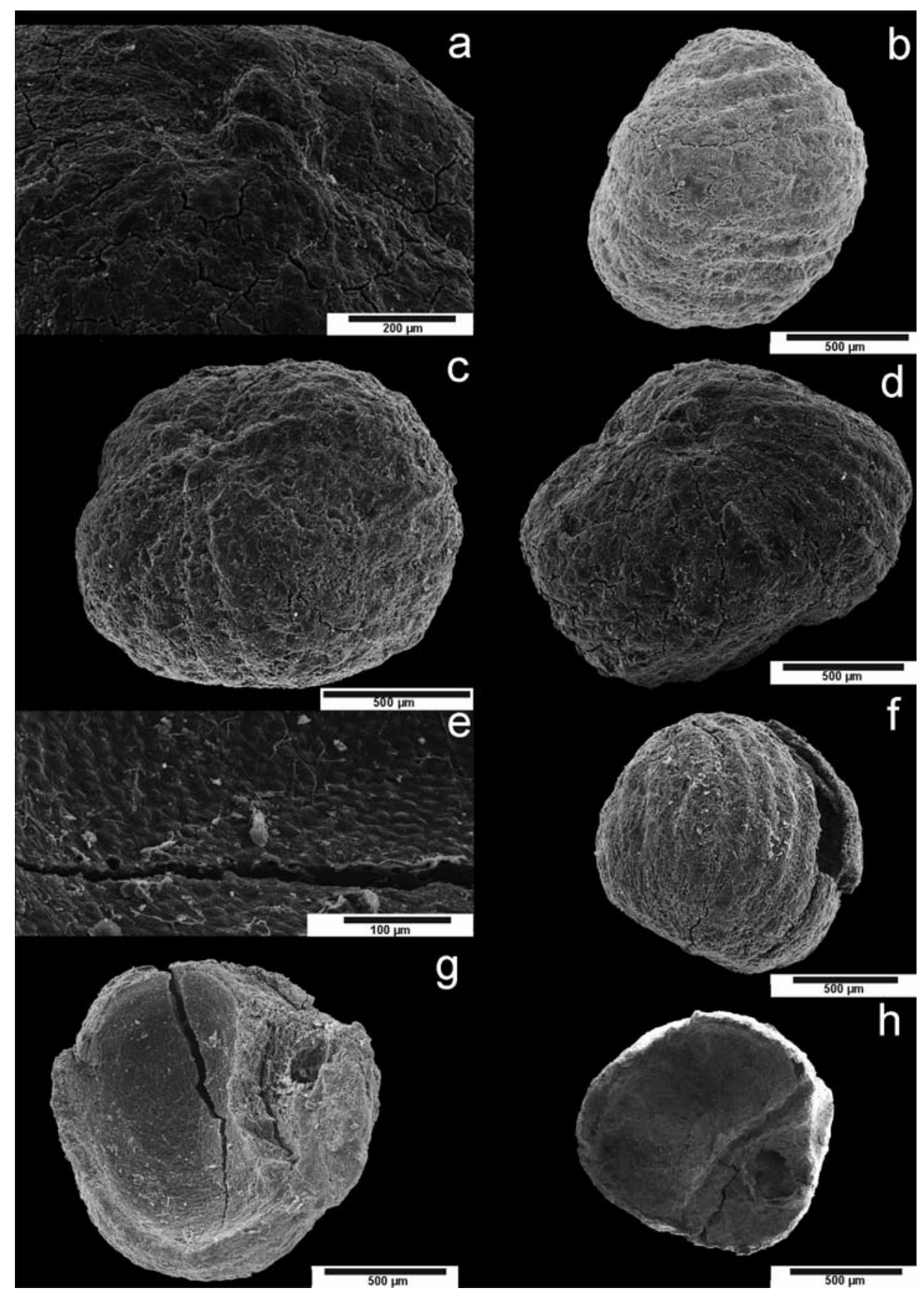

Central European Geology 55, 2012 
Plate 4

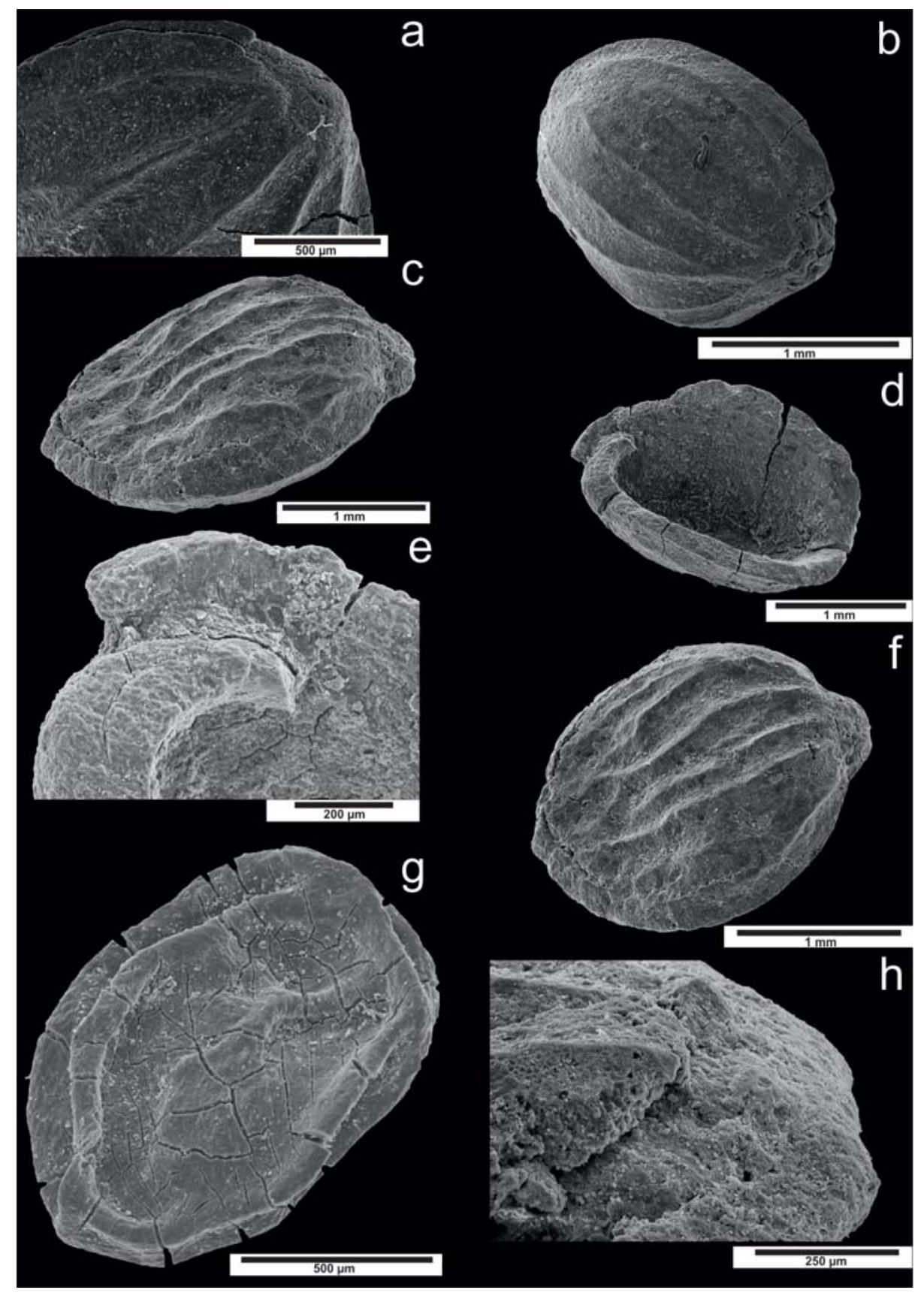

Central European Geology 55, 2012 